\title{
“INSPIRATION AND SUCCESS FOR ALL LEARNERS": HOW DO VIETNAMESE EFL SCHOOL TEACHERS PERCEIVE THEIR ROLES AND WHAT STYLE OF TEACHER ARE THEY IN THE ERA OF INDUSTRY 4.0?
}

\author{
Hoang Van $\operatorname{Van}^{1 *}$ \\ VNU University of Languages and International Studies, \\ Pham Van Dong, Cau Giay, Hanoi, Vietnam
}

Received 19 April 2019

Revised 20 May 2019; Accepted 28 May 2019

\begin{abstract}
This research is an attempt to highlight how Vietnamese EFL school teachers perceive their roles and what style of teacher they are in this current changing world - the world of Industry 4.0. The study involved a sample of 300 Vietnamese EFL school teachers throughout Vietnam. The instruments employed for the research were three questionnaires intended to explore different aspects of EFL teachers' perception of their roles. The data collected were analyzed quantitatively and were discussed in some detail. The research brought to light a number of significant findings of which five are prominent: (i) Vietnamese EFL school teachers displayed a relatively good understanding in identifying what roles are of traditional teacher style (TTS) and what roles are of modern teacher style (MTS); (ii) they rated as high and medium most of the roles of the TTS and reported having performed most of them; (iii) they rated as low some of the roles of the TTS but still kept on performing them; (iv) they rated as very high, high and medium most of the roles of the MTS, but only $2 / 3$ of them were reported having been performed; and (v) they rated as medium many of the remaining roles of the MTS which belong to what has commonly been referred to in modern EFL/ESL pedagogy as the learner-centred approach in communicative language teaching (CLT), but the number of these roles reported having been performed were very modest. Based on the interwoven information obtained from the three questionnaires, it was suggested that although the era of Industry 4.0 is a reality, many of the Vietnamese EFL school teachers seem to be on the traditional side of the traditional $\leftrightarrow$ modern teacher style scale. It is recommended that teacher role should be a legitimate component in all EFL teacher training and teacher professional development (PD) programmes in English teacher education departments/faculties in Vietnam to help EFL teachers be better familiarized with their roles, particularly those required in modern EFL/ESL education, so that they can perform their roles more effectively and more appropriately in their teaching for the success of their students as they move along their "journey of learning" (Pullias \& Young, 1968: 32) a new means of communication. ${ }^{2^{* *}}$
\end{abstract}

Keywords: teacher role, traditional teacher role, modern teacher role, teacher role-pertained responsibility, traditional $\leftrightarrow$ modern teacher style scale

* Tel.:84-946296999, Email: vanhv.sdh@gmail.com; vanhv@vnu.edu.vn

** This paper was presented at the plenary session of the $4^{\text {th }}$ VietTESOL International Conference entitled Inspiration and Success for All Learners held at Ho Chi Minh University of Education on 7-8 December, 2018. 


\section{Introduction}

"The mediocre teacher tells. The good teacher explains.

The superior teacher demonstrates. The great teacher inspires."

(William Arthur Ward)

We are living in the age where information and communication technology are developing rapidly. In the field of education, "Computers [and many smart and modern electronic devices, I would add] are now, for teachers and students, the gateways to a wealth of information, contacts, and activities. The use of the Internet has mushroomed - indeed some countries have wired up their entire public education systems - and the technology for self-study, language laboratories, and computer corpora has developed far beyond what many have anticipated" (Harmer, 2005: ix). In the field of teaching generally, there has been in recent decades a strong tendency to move from the "teacher-centred approach" to what has been referred to as the "learnercentred approach". And in the field of second and foreign language teaching particularly there has been a tendency to move from the often undefined notion of "non-communicative language teaching" to the relatively clearlydefined notion of "communicative language teaching (CLT)". The final aim of these "new" approaches, in the context of foreign language education, is that the students will become independent learners and more effective language communicators, and the teacher, among other things, will become an inspirer or a source of inspiration for the students' learning (cf. Breen \& Candlin, 1980; Nunan, 1991; Tudor, 1993, 1994; Richards \& Rodger, 2001; Jones, 2007).

In mid-June 2018, I was invited by the National Foreign Languages 2020 Project to write a paper for the $4^{\text {th }}$ International
VietTESOL Conference that would be held on 7-8 December, 2018 at the University of Education, Ho Chi Minh City. I accepted the invitation with delight and began to look for the details of the Conference. I emailed Dr Nguyen Ngoc Vu, former Dean of the English Faculty of the University, and in next to no time I received an email in reply from him with an attached file containing a tentative title which read: "Inspiration and Success for All Learners". The title, as I perceived of it, may have a number of readings, but if we read it as "If the teacher inspires, all the learners will succeed", we can see that the meaning of the Conference is realized by a complex sentence with "If the teacher inspires" being the subordinate clause, and "all learners will succeed" the main clause. I am not a learner in the proper sense of the word. So naturally I would choose a topic within the domain of the subordinate clause. But what topic specifically should I choose so that it could engage the wide and diverse range of interests of the experts (Vietnamese and international language scholars, second or foreign language school and university teachers, and EFL post graduate students perhaps) who would be present here on this occasion? It took me quite a while to get my topic cap on. Finally, being happy with the idea that no topic could cover even a small aspect of the Conference, I decided to choose the topic which I thought would be the concern of the majority of EFL teachers in Vietnam under the rubric of my title, "Inspiration and Success for All Learners: How do Vietnamese EFL School Teachers Perceive their Roles and What Style of Teacher are They in the Era of Industry 4.0?" By delivering this topic, I want particularly to speak to those who are teaching English in schools, to those in preparation for teaching, and perhaps to others who have an interest in teaching English as a second or foreign language. My experience as a 
classroom teacher and my close work with EFL school teachers over many years have led me to see that EFL school teachers are doing teaching every day, but not so many of them are fully aware of their roles, and that quite a few of them often get confused and even bewildered when they are told to perform new roles in a new teaching method/ approach. As a result, they begin their work with joy and hope but gradually lose their love for the profession under the severe demands and pressure of teaching. So, together with other things that make up "the good language teacher" (Prodromou, 1994: 18), a better understanding of the roles of the teacher will help them reduce their becoming dull, continue their professional growth toward excellent teaching, so that they can act as effective inspirers for their students. My paper will fall into five parts. Following Part one which presents the reasons for choosing the topic, Part two is concerned with a literature review in which I will examine representative related studies on teacher roles. This is followed by Part three where I will present the design and methodology of my research. Part four constitutes the focus of the research in which I will present research findings and discussion of the findings. And finally in Part five, I will summarize the main points of the research, provide conclusions drawn from the research findings, point out limitations and make suggestions for further study.

\section{Literature review}

The conceptualization of teacher role has attracted scholars from a vast range of broader views over the past decades. Researches on this topic in education generally and in language teaching particularly are numerous. But for the purpose of this research, six seem to be relevant: "A Teacher is Many Things" by Earl V. Pullias \& James D. Young (1968), “Aspects of Language Teaching” by Henry G.
Widdowson (1999), "Teaching and Learning in the Language Classroom" by Tricia Hedge (2000), "Reflective Teaching in Second Language Classrooms" by Jack C. Richards \& Charles Lockhart (2004), "The Practice of English Language Teaching" by Jeremy Harmer (2005), and "Learning Teaching" by Jim Scrivener (2009).

"A Teacher is Many Things" is the first work selected for review because it is a classic, lucid, succinct and penetrating book on the role of the teacher generally. It was written by two eminent American educators Earl V. Pullias and James D. Young and was published by Fawcett Publications in 1968. In this book, "drawing upon their own extensive experience in the classroom, the authors [Pullias \& Young] describe and evaluate the varied and constantly expanding roles every school teacher must assume to be successful" (cited from back cover of the 1977 version). The book, as Pullias \& Young claim, is intended to address those who are teaching, those in preparation for teaching, and thoughtful parents and other citizens who have an interest in the teaching art (p. 9). The authors begin their book by examining the notion of teaching (in Chapter 1). They claim that teaching is a complex job and that it is both a science and an art. The teacher, therefore, must know the subject she is teaching; at the same time she must have knowledge about the subjects that are related to her subject; and she must have knowledge of human psychology. Apart from these aspects, in teaching the teacher must balance many factors in her actual performance such as knowledge, skills, and qualities of personality, etc. Pullias \& Young (Ibid.) discuss nine obstacles which are thought to hinder the teacher's excellent teaching (in Chapter 2): (i) cynicism (caused by the teacher's doubt that nothing is perfect), (ii) narrowness (caused by the teacher's tendency of being too much specialized in a subject), 
(iii) confusion (caused by the teacher's failure to understand the meaning of her work and her part and purpose in life), (iv) false ideas about people (caused by the teacher's subjective judgements about people), (v) disorder (caused by the teacher's need to do more, learn more, and get more in a crowded and disorderly life), (vi) dead knowledge (caused by the teacher's presenting the knowledge she gained from the past which is of less or no meaning to students), (vii) poor imagination (caused by the teacher's lack of imagination which makes students bored), (viii) routine (caused by usual or dull order in which the teacher does things everyday), and (ix) ways of working (caused by the teacher's failure to develop a style suited to her work). Chapters 3 through 16 constitute the focus of Pullias \& Young's study. Here the authors present 14 roles the teacher is generally assumed to take: (i) A Teacher Is a Guide (Chapter 3), (ii) A Teacher Is a Teacher (Chapter 4), (iii) A Teacher Is a Modernizer (Chapter 5), (iv) A Teacher Is an Example (Chapter 6), (v) A Teacher Is A Searcher (Chapter 7), (vi) A Teacher Is a Counsellor (Chapter 8), (vii) A Teacher Is a Creator (Chapter 9), (viii) A Teacher Is an Authority (Chapter10), (ix) A Teacher Is an Inspirer of Vision (Chapter 11), (x) A Teacher Is a Doer of Routine (Chapter 12), (xi) A Teacher Is a Breaker of Camp (Chapter 13), (xii) A Teacher Is a Storyteller and an Actor (Chapter 13), (xiii) A Teacher Is a Facer of Reality (Chapter 15), and (xiv) A Teacher Is an Evaluator (Chapter 16). Each of these 14 roles is defined, explained and discussed in detail to make the book a comprehensive and an entertaining piece of research. This explains why published over half a century ago in a country (the USA) whose culture is different from the culture of Vietnam, most of the teacher roles suggested in "A Teacher is Many Things" are still valid in modern education, and are of particular use for modern researchers on the roles of the teacher.

\section{"Aspects of Language Teaching" was} written by the famous British applied linguist Henry G. Widdowson. Despite the fact that the title of the book is a bit ambiguous ${ }^{1}$, the contents presented in it have proved that it is a scholarly piece of work, and is something that deserves to read. Widdowson's book consists of 11 chapters; and of these 11 chapters he devotes one (Chapter 11) to discussing the roles of the language teachers and learners. What seems to be of interest is that different from other studies on teacher role, Widdowson's study seems to be theoretical; it is not concerned with identifying the roles and responsibilities the teacher is assumed to take. Widdowson begins his chapter by defining the notion of role. Using the definition of role by Banton (1965: 29), Widdowson (1999: 181) defines a role generally as "a set of norms and expectations applied to the incumbents of a particular position". $\mathrm{He}$ explicates the term "incumbents", referring it to the positions taken up by teachers and pupils in the classroom. He then raises two questions for exploring the roles of the language teachers and learners: "What are the norms and expectations associated with these [teacher and student] particular roles?", and "What particular positions do the incumbents occupy?" In response, Widdowson (Ibid.), drawing on Hymes's (1972) research, argues that the classroom, seen from the point of view of both physical surroundings (settings) and socio-psychological context (scene), provides the context for the enactment of these roles. According to Widdowson,

\footnotetext{
The title of the book is ambiguous because it does not explicate specifically the meaning of the term "language". The reader may find it difficult to understand what the author means by the term, whether it is language generally or the English language generally or the English language as a first language, a second language, or a foreign language.
} 
physical surroundings may facilitate or constrain certain interactive procedures, while sociopsychological context may help recognize how roles are assumed by classroom incumbents: the teacher and the students. He then discusses the term "role" at some length, distinguishing two kinds of role enacted in the classroom. The first kind, he maintains, has to do with occupation and is identifying and categorizing (e.g. pupil, student, master, mistress), and the second one has to do with activity and is temporary and accidental (e.g. learner). He claims that the term "teacher" is ambiguous, referring to both an identifying and categorizing role and a temporary and accidental activity role (p.183). Based on this distinction, Widdowson examines two kinds of classroom engagement. The first kind of engagement involves the identifying roles: the teacher in social interaction with the pupil. He refers to it as interactional engagement whose norms and expectations, as he explains, defining appropriate behaviour are social attitude and educational ideology. It reflects the way educationists believe students should be socialized. There is another kind of classroom engagement which Widdowson calls transactional purpose. This kind of engagement instigates activities directed at achieving learning goals, and it consists of two accidental roles: teacher as teaching person on the one hand and learner as learning person on the other. The norms and expectations in this kind of engagement, as Widdowson explains, relate to pedagogic purpose; and "the ways of defining roles are likely to be the most effective for dealing with a particular subject, for developing specified knowledge and skills, for meeting the demand of the examination" (p.184).

In the second section of the chapter, Widdowson discusses teacher role in relation to "teacher authority and learner autonomy" (p. 187). He observes that, at least in Western education, the teacher as a possible agent of authority which seeks to maintain the power of privilege, schooling pupils into obedient compliance has come under suspicion. He cites Cicero in support of his belief that "Most commonly the authority of them that teach hinders them that would learn" (p. 187). He then identifies general teacher roles by making a distinction between what he refers to as "exercise of authority in interaction" and "exercise of authority in transaction". According to Widdowson, in the exercise of authority in interaction the teacher's role as professeur (teaching person) is more or less authoritarian (a role ascribed to the teacher by the society in which she can claim a superior and dominant position, and her dominance over the students is based on right). In the exercise of authority in transaction, in contrast, the teacher's role as enseignment (expert) is more or less authoritative (a role derived from the teacher's being an expert, and her dominance over the students is based not on right but on knowledge).

It seems from Widdowson's discussion that of the two teacher roles, he favours the authoritative (non-authoritarian) one as, he explains, this approach can help students "feel secure and non-defensive to enable them to learn not because the teacher demands it of them, but because they need to in order to accomplish their own goals" (Widdowson, 1999: 188, citing Talyor, 1987: 58). However, he draws attention to the reader that the exercise of the non-authoritarian approach does not mean that the teacher abdicates her fundamental authority to guide and structure her class. He goes on to state: “... no matter how we view pedagogy, no matter how much initiative we believe should be allowed to the learner, the teacher as enseignment [expert] must surely retain an undiminished authority. $\mathrm{He}$ or she still has to contrive the required enabling conditions for learning, still has to monitor and guide progress" (p. 189). 
Widdowson's chapter on teacher role is useful for researchers, language teachers, particularly foreign language researchers. Apart from pointing out the differences between traditional and modern teacher styles, his chapter makes a clear distinction between teacher as authoritarian and teacher as authority, the two terms/roles which often cause confusion and misunderstanding among researchers and teachers in language teaching in general and in EFL in particular.

"The Practice of English Language Teaching" was written by the influential English language teaching methodologist Jeremy Harmer. Unlike Widdowson, the title of Harmer's book is less ambiguous as it contains in itself the classifier "English" in the noun phrase "English Language Teaching". There is, however, still some ambiguity in it as we still do not know whether "English Language Teaching" refers to the teaching of English as a first, a second or a foreign language. The book, as Harmer claims, is targeted at practising teachers and those studying on in-service training programmes and post graduate courses. It consists of 24 chapters, covering various aspects of the English language and English language teaching. Of the 24 chapters, Harmer devotes a separate chapter (Chapter 4) to describing the teacher and her roles. Although Hamer does not explicate or theorize how he identifies teacher roles, it can be inferred from his presentation that his "framework deals exclusively with roles that relate to classroom procedure. Other frameworks include categories which move beyond the immediate pedagogic concerns which are influenced by attitudes in the social and cultural environment" (Hedge, 2000: 27). Harmer's chapter on teacher role is organized into four parts. Part one is concerned with an answer to the question, "What is a teacher?" and some problems relating to teachers and leaners in the learner-centred approach. Part two presents 8 teachers roles: controller, organizer, assessor, prompter, participant, resource, tutor, and observer. Each of these roles is defined, described, and discussed in some detail. To guide teachers how to perform these roles successfully in the classroom, Harmer provides them with many practical and useful tips. Part three is devoted exclusively to the description and discussion of the teacher as performer (actor). It seems from Harmer's discussion that the teacher as performer is one of the key roles the modern language teacher should take on. He likens the role of the teacher as performer in the classroom to that of the actor on the stage: "Just as stage directions give the actors an insight into what lines mean, so similar description in teaching may give us insights into how activities can best be managed" (p. 64). What seems to attract readers' attention is that linguistically Harmer employs a number of manner adjuncts (adverbs) to describe the behaviours or the ways the teacher is advised to perform her roles in the classroom for students' effective communication activity. Below is what he succinctly states (italics added):

... for an activity where students are involved in a team game, we will want to behave energetically (because a game needs excitement and energy), encouragingly (if students need a nudge to have a go), clearly (because we do not want the game fail through misunderstanding) and fairly (because students care about this in a competition situation). If, on the other hand, students are involved in a role-play we should perform clearly (because students need to know exactly what the parameters of the role-play are), encouragingly (because students may need prompting to get them going), but also retiringly (because, once the activity has got going, we do not want to overwhelm the students' performance) and supportively (because students may need help at various points (Harmer, Ibid.: 64). 
In Part four of this chapter, Harmer looks at the role of the teacher as teaching aid. He mentions three roles: mime and gesture, language model, and provider of comprehensible input. Mime and gesture, according to Harmer, help the teacher to convey meaning to students on the spot; language model means that the teacher models language herself for students to follow; and provider of comprehensible input means that outside the classroom, if student can access to English, it is the English that frequently appears incomprehensible to them. In learning context, only the teacher knows her students' level of English and can provide them with comprehensible English which a textbook or an audio CD cannot.

It can be said in summary that Harmer's chapter on teacher role is of particular significance to language teachers in general and EFL teachers in particular. It presents and describes in a clear style a number of English language teacher roles, some of them are traditional, some others are modern, and some others seem to be of both. It not just tells teachers what roles they should take and gives them insights into classroom behaviour so that they can understand their roles but also helps them how to perform these roles appropriately and effectively in their work.

In "Reflective Teaching in Second Language Classrooms", Richards \& Lockhart (1995) devote a chapter to discussing the roles of the second language teacher. Drawing on insights from Ellis \& McClinton (1990), Richards \& Lockhart define role generally as "the part taken by a participant in any act of communication" (p. 97). According to Richards \& Lockhart (Ibid.), there are a number of factors that create and influence the roles of the teacher, but four seem to be of particular importance: (i) institutional factor, (ii) teaching approach or method factor, (iii) teacher's personal views, and (iv) cultural factor.
With regard to the institutional factor, Richards \& Lockhart claim that different teaching settings create particular roles for teachers based on the institutional administrative structure, the cultural operating in each institution, and its teaching philosophy. They contrast teacher roles in a "traditional school" with those in a "modern school". In the traditional school, they state, the senior teacher or head of teaching group makes most of the key decisions; the teaching schedules are issued by the school; and the teacher is seen primarily as someone who carries out those decisions that have been made. In the modern school, in contrast, many teachers can serve as course coordinators in rotation; the courses the students must follow are not fixed; counsellors work with the students when they come into the programme; the teachers can make their own decisions about course goals and syllabus content, and how they should teach and monitor their own classes. Based on the institutional factor, Richards \& Lockhart identify eight teacher roles many of which can be said to belong to the learner-centred approach to second or foreign language teaching: needs analyst, curriculum developer, material developer, counsellor, mentor, team member, researcher, and professional.

Concerning teaching approach/method factor, Richards \& Lockhart maintain that some methods or approaches in language teaching define specific roles for teachers and prescribe the kinds of behaviours in which they should or should not allow in the classroom. In the audiolingual method, for example, the teacher is assumed to play the central and active role. She is the model of the target language for the students to follow, the controller and director of the pace of learning, the monitor and corrector of students' performance (cf. Richards \& Rodgers, 1996: 56, 2001: 62). In active teaching and other methods which rely less on teacher-directed 
teaching, the teacher is thought to play the roles of a knowledge presenter, an explainer, a manager, a monitor, a feedback provider, a responsibility sharer, a lesson organizer, and a coordinator (Tikunoff, 1985; Hyland, 1991). And in the communicative approach to language teaching, the teacher is suggested to play the roles of a facilitator, an independent participant, an organizer, a guide, a researcher, and a learner (Breen \& Candlin, 1980).

With reference to teacher's personal views factor, Richards \& Lockhart observe that although many teachers have been trained to use a specific method of teaching or asked to teach within a philosophy established by their institution, very few of them have ever followed that method of teaching in its entirety (unless they work in a setting that demands they do and carefully monitor adherence). Instead, the way they teach often reflects their personal interpretation of what they think works best in a given situation. Based on the teachers' descriptions of how they see their role, Richards \& Lockhart suggest the following teacher roles: planner, manager, quality controller, group organizer, facilitator, motivator, empowerer, and team member.

And in regard to the cultural factor, Richards \& Lockhart state that teaching is an activity which is embedded within a set of culturally bound assumptions about teachers. These assumptions define the roles the teacher is believed to take. They prove their point by pointing out the differences between Western and Oriental education. Western education, according to the authors, focuses more on individual learner creativity and encourages the teacher to facilitate independent learning. Oriental (Chinese) education, in contrast, focuses more on the learner's mastering a body of knowledge presented/transmitted by the teacher, and both the teacher and the learner are concerned with the end product of learning, i.e. students are expected to reproduce the knowledge in the same form as it is transmitted by the teacher (see also Widdowson, 1999; Scrivener, 2009).

There are at least three merits in Richards \& Lockhart's chapter. First, it provides insights into the various factors that create and influence the roles of the teacher. Secondly, like the studies by Widdowson and Harmer, it suggests a number of language teacher roles, some of them are of traditional teacher style, some others are of modern teacher style, and some others seem to be of both. And third, it points out some main differences between Western and Oriental (Chinese) education systems.

"Teaching and Learning in the Language Classrooms" is a book of 447 pages long. In this book, Hedge (2000) discusses a number of aspects concerning language teaching and learning. Unlike Widdowson, Richards \& Lockhart, and Harmer, Hedge does not examine teacher role in a separate chapter. Instead, she incorporates the problem into a broader framework referred to as "the framework for teaching and learning in the learning process" (p. 26). Hedge begins her examination of the role of the language teacher by analyzing the sample of lesson notes from the Teacher's Book and the corresponding section from the Student's Book entitled "Pre-intermediate Choice". She notices that the activities move from teachercentredness (the teacher takes a dominant role in largely teacher-fronted classroom) to learner-centredness (students do pair works). Then employing the framework suggested by Harmer (1991), Hedge is able to identify the language teacher in a number of roles in this lesson: controller, assessor, corrector, organizer, monitor, feedback provider, resource. To support her research, Hedge briefly presents Karava-Duka's (1995) study undertaken with a multicultural group of experienced teachers from differing 
worldwide contexts and representing a wide range of teaching approaches. The author (Karava-Duka) asked the teachers what roles they perform as teachers. She arrived at a

1. Source of expertise (46.4\%)

1.1 Denoting authoritarian stance?

Instructor

Presenter

Actor

Pedagogist

2. Management roles (35.7\%)

Manager

Organizer

Director

Administrator

Public relation officer

Arranger

4. Facilitator of learning (64.2\%)

Learning facilitator

Helper

Guide

Catalyst to group discussion

Prompter

Mediator

6. Caring roles (25\%)

Friend

Sister/Mother

Caretaker

Supporter

8. Evaluator (10.7\%) below list of roles which are subsumed under 9 categories and the corresponding percentage of teachers who mentioned the functions pertaining to a particular category.

1.2 Denoting supportive stance?

Informant

Input provider

Information provider

Resource

Source of knowledge

3. Source of advice (53.5\%)

Counsellor

Advisor

Personal Tutor

Psychologist

Listener

5. Sharing roles $(17.8 \%)$

Negotiator

Participant

Student

Cooperator

7. Creator of classroom atmosphere

(14.2\%)

Entertainer

Motivator

Source of inspiration

9. Example of behaviour and hard work $(3.5 \%)$

(Hedge, 2000: 28-9, citing Karavas-Dukas, 1995)

Hedge then discusses some typical roles teachers perform in a traditional and contemporary second language class, and some aspects of teacher competence such as ability to plan an effective lesson, to manage activities and interactions successfully, to monitor learning, to give instructions, and to give feedback.
There are at least two merits concerning Hedge's study. The first is that it looks at the problem of teacher role from a more practical perspective: from the teaching steps suggested in a Teacher's Book. And the second one is that it provides (although not fully and explicitly presented) a useful list of teacher roles (both 
traditional and modern) subsumed under a number of general role categories.

Scrivener, in his book "Learning Teaching" (2009), devotes a small but significant section to discussing the roles of the language teacher. Based on the teacher's teaching style, he broadly categorizes the language teacher as having three roles in relation to teaching which he refers to respectively as (i) the teacher as the explainer, (ii) the teacher as the involver, and (iii) the teacher as the enabler. By "the teacher as the explainer", Scrivener means one who relies mainly on 'explaining' or 'lecturing' as a way of information to the students. He states that done with this teaching style, this teacher's lessons can be very interesting, entertaining, and informative. The students are listening, perhaps making notes, but are mostly not being personally involved or challenged. They often get practice by doing individual exercises after one phase of the lecture has finished. By "the teacher as the involver", Scrivener wants to emphasize the fact that the teacher knows the English language and how it works. She is also familiar with teaching methodology. She is able to use appropriate teaching and organizational procedures and techniques to help her students learn English. Explanation may be one of the techniques. But what she does is to involve the students actively and put a great effort into finding appropriate and interesting activities that will do this, while still retaining clear control over the classroom and what happens in it. And by "the teacher as the enabler", Scrivener maintains that the teacher is confident in sharing control with the students, or perhaps to hand it over to them entirely. Decisions made in her classroom may often be shared or negotiated. In many cases she takes her lead from the students, seeing herself as someone whose job is to create the conditions that enable the students to learn for themselves.
She may become a 'guide' or a 'counsellor' or a 'resource' of information when needed. Sometimes when the class is working well, when a lot of autonomous learning is going on, she may be hardly visible.

Scrivener's conceptualization of teacher role is useful not only for the practical teacher but also for the research teacher. His examination of teacher role, although not comprehensive, provides useful insights into three important general teacher roles under which there are a number of other specific roles (both traditional and modern).

It can be seen from the reviewed literature that studies on teacher role are numerous. It is, therefore, not surprising that the problem can be approached from different perspectives: from education generally (the study by Pullias \& Young) to language education particularly (the studies by Widdowson and Hedge), and to English language education more specifically (the studies by Harmer and Scrivener). It can also be seen from the reviewed literature that different researchers tackle the problem of teacher role from different levels: some seem to look at the problem from a more theoretical level (Widdowson and Richards \& Lockhart), while others seem to explore it from a more practical one (Harmer, Hedge, and Scrivener). In regard to the identification of teacher roles, different researchers seem to approach the problem in a different way: some confine their research to the prescripted roles the teachers perform in the classroom (Hedge, Scrivener, and Harmer); others extend their research to the roles the teachers perform outside the classroom (Pullias \& Young and Richards \& Lockhart). Still, some identify and describe teacher roles by exploring teacher's personal view, institutional philosophy, the influence of teaching approach or teaching method, and the cultural context in which teachers work (Richards \& Lockhart), others seem to 
approach the problem by making a distinction between what has been commonly referred to as traditional teaching style (related to the teacher-centred approach) and modern or “enlightened", to use Widdowson's (1999: 186) term, teaching style (related to the learnercentred approach). However, what they seem to have in common is that all of them consider teacher role an important aspect of teaching, and all appear to favour the idea that traditional teaching style seem "to impede the natural learning process for it does not allow for learner initiatives; it does not give the learner scope to draw on the available resources of intuition and inventiveness, or to engage freely the procedures for learning which he or she has acquired through a previous experience of language" (Widdowson, 1999: 186). There are, however, at least three gaps that remain unacknowledged by most of the studies reviewed. First, most of the studies seem to have focused on examining teacher role and the nature of teacher role generally: what it is, how it is classified, and what teachers should do to fulfil their roles. Secondly, most of the studies seem to have been conducted by western scholars; their attitudes towards traditional and modern teacher roles, therefore, seem to be somewhat Western-biased. Thirdly, and more importantly, no research has ever attempted to examine how teachers, particularly EFL teachers, perceive their roles and to identify what style of teacher they are in a specific teaching context. These remarks take me to Section 3, where I will present the design and methodology of my research.

\section{Research design and methodology}

\section{Aim and objectives}

The overarching aim of this research is to examine how Vietnamese EFL school teachers perceive their roles and to identify what style of teacher they are in the current changing world. To fulfil this aim, the study sets for itself the following objectives:

1. Finding how Vietnamese EFL school teachers identify teacher styles.

2. Finding how Vietnamese EFL school teachers rate teacher roles through teacher role-pertained responsibilities.

3. Exploring what roles Vietnamese EFL school teachers have performed and what roles they haven't performed in their actual teaching.

4. Locating the current Vietnamese EFL school teachers on the traditional $\leftrightarrow$ modern teacher style scale.

\section{Research questions}

The above aim and objectives can be translated into the following questions for exploration:

1. What roles do Vietnamese EFL school teachers think are of traditional teacher style, and what roles do they think are of modern teacher style?

2. How do Vietnamese EFL school teachers rate the importance of teacher roles through teachern rolepertained responsibilities?

3. What roles have Vietnamese EFL school teachers performed and what roles haven't they performed in their actual teaching?

4. What style of teacher are Vietnamese EFL school teachers in this era of Industry 4.0 ?

\section{Research instrument}

To accomplish the aim and the objectives, and to answer the research questions, the research employs three questionnaires. The reason for choosing questionnaires is that of all research instruments, questionnaire is the most 
commonly used format (cf. Trochin, 2005; Cohen, Manion \& Morrison, 2007); it is the least expensive which can be sent to a large number of respondents and can allow easy and quick data collection (Robinson, 1991; BargielaChiappini; Brown, 2007; Nickerson \& Planken, 2007). The reason for not using other research instruments such as interview is that although interview may play a compensation role for the limitations presented in the questionnaires and can help the researcher with additional information from the participants and confirm their responses in the questionnaires, it is not possible to set up meetings with the participants as they are scattered throughout Vienam, not to mention the fact that many of them are not comfortable to meet with a man (myself) who they know is two or three decades their senior. It is not easy to conduct interviews online or via telephone with the participants either as it is time-consuming and the information obtained from this channel cannot be claimed to be as reliable (cf. Brown, 2007).

The three questionnaires were designed as follows. First, each of the questionnaires was designed into two parts. The first part is to get the participants' personal background information, including their name and their phone number (if possible), their level of teaching (primary, lower secondary or upper secondary school), their gender, their teaching experience, and location of the school where they are working. For the second part, based on my experience as an experienced EFL teacher for quite a number of years, and on the studies by scholars such as Pullias \& Young (1968, 1977), De Lopez (1994), Prodromou (1994), Tudor (1996), Widdowson (1999), Hedge (2000), Scrivener (2009), Harmer (2005), Keller (2011), Archana \& Rani (2016), I developed a list of 45 items of teacher roles and a list of 45 items of teacher role-pertained responsibilities. Then modified after Kavaras-Dukas (1995, cited in Hedge,
2000), these 45 teacher roles and their pertained responsibilities were grouped into 9 basic concepts or general role categories: (i) source of expertise (5 items), (ii) management (11 items), (iii) source of advice (3 items), (iv) facilitation of learning (8 items), (v) responsibility sharing (4 items), (vi) care taking (2 items), (vii) Professional developing (7 items), (viii) assessing \& evaluating (3 items), and (ix) example of behaviour (2 items). The list of 45 items of teacher roles is employed for two purposes: one (Appendix 1, Questionnaire 1) is to get information from EFL school teachers about how they identify teacher styles through the given 45 teacher roles, and the other (Appendix 3, Questionnaire 3) is to ask them to state what roles they have performed or are performing and what roles they haven't performed or are not performing. And the list of 45 items of teacher role-pertained responsibilities (Appendix 2, Questionnaire 2) is to explore how EFL school teachers rate the importance of teacher roles through these teacher rolepertained responsibilities. The rating is done on a five-point scale: $\mathbf{1}=$ Not at all important, $\mathbf{2}=$ Not very important, $3=$ Important, $4=$ Very important, and $\mathbf{5}=$ Totally important. The three questionnaires were piloted by 10 EFL school teachers. The vetting process was employed to identify possible vagueness in the questionnaire items and to adjust both the language and format.

Three things should be noted here. First, there are more teacher roles and teacher rolepertained responsibilities than those provided in the questionnaires. Secondly, there may be more than one responsibility pertaining to a teacher role, but for the purpose of this study only one responsibility pertaining to a teacher role is selected. And thirdly, some of these roles may overlap, and the role categories and their pertained responsibilities are in no particular order of priority. 


\section{The participants}

The participants involved in this research were primary, lower secondary and upper secondary teachers of English in schools throughout Vietnam. They were MA students in English language linguistics and English language teaching methodology at the University of Languages and International Studies - Vietnam National University, Hanoi (VNU ULIS). The majority of others were from different provinces in Vietnam who attended training workshops on the implementation of MoET's new ten-year English curriculum and textbooks. The total number of participants agreed to take part in the research were 366. The number of questionnaires completed and returned were $334(91.2 \%)$. Of the 334 returned questionnaires, $300(89.8 \%)$ were valid and were determined as data set for analysis and discussion. Of the 300 surveyed participants, $101(33.6 \%)$ are primary teachers, $114(38 \%)$ are lower secondary teachers, and 85 (28.3\%) are upper secondary teachers, $280(93.3 \%)$ are female, $20(6.7 \%)$ are male, $116(38.6 \%)$ have been teaching English for 1-10 years, 122 (40.6\%) have been teaching English for 1120 years, and $62(20.6 \%)$ have been teaching English for over 20 years, 108 (36\%) are from urban areas, $95(31.6 \%)$ are from suburban areas, and 97 (32.4\%) are from rural areas. Table 1 below provides the participants' main demographic profiles. (Percentage rounded to the nearest figure).

Table 1. Participants' main demographic profiles

\begin{tabular}{|l|l|c|c|}
\hline \multicolumn{1}{|c|}{ Information } & \multicolumn{1}{|c|}{ Details } & Number $(\mathbf{N}=\mathbf{3 0 0})$ & Percentage \\
\hline Level of teaching & Primary & 101 & 33.6 \\
& Lower secondary & 114 & 38.0 \\
& Upper secondary & 85 & 28.3 \\
\hline Gender & Female & 280 & 93.3 \\
& Male & 20 & 6.7 \\
\hline Years of teaching experience & $1-10$ years & 116 & 38.6 \\
& $11-20$ years & 62 & 40.6 \\
& $>20$ years & 108 & 20.6 \\
\hline School geographical & Metropolitan areas & 95 & 36.0 \\
location & Suburban areas & 97 & 31.6 \\
& Rural areas & & 32.4 \\
\hline
\end{tabular}

\section{Data collection procedure}

Being a post-graduate lecturer, the general editor and a co-author of MoET's new tenyear English textbook series for schools in Vietnam, and an EFL teacher trainer gave me a relatively high degree of freedom to ask EFL MA students and EFL school teachers to take part in the research. Not surprisingly, most of the participants who attended my MA courses at VNU ULIS and training workshops for MoET's new ten-year English curriculum and textbooks agreed to be my survey respondents. The surveys were conducted after class and workshop time. The questionnaires were administered directly to the participants one at a time. Each survey questionnaire took about 30 minutes on average. In the completing process, the participants were well provided with explanations of the research, and they had opportunities to ask questions related to the items in the questionnaires they wanted the researcher to clarify. Those participants who could not complete their questionnaires could bring them home and handed them over to the researcher the next day.

The data collected were then analyzed quantitatively for the frequency and percentage of each role category and each role-pertained responsibility item, and for each rating scale 
as well as the mean score of the role items (in Questionnaire 2).

\section{Findings and discussion}

Objective 1: Findings relating to how Vietnamese EFL school teachers identify teacher styles from teacher roles

Question 1: What roles do Vietnamese EFL school teachers think are of traditional teacher style, and what roles do they think are of modern teacher style?

It should be noted here that the decision on whether a teacher role is of traditional or modern teacher style is not an easy task, for there are no unanimous answers on the part of the surveyed teachers to whether a teacher role belongs absolutely to a teacher style. To decide whether a particular teacher role belongs to a particular teacher style, therefore, we have to set a working principle for ourselves. In this research, we will use "majority rule" as the basis for determining what teacher role belongs to what teacher style. This means that when over $50 \%$ of the participants identify a teacher role as belonging to traditional teacher style, it is counted as the role of the traditional teacher style and vice versa. Based on this principle, we now turn to report on how Vietnamese EFL school teachers respond to the first research question. We will begin with reporting on how EFL teachers identify teacher style in the 9 general role categories. Then we will present in some detail how they respond to each role item in the Questionnaire.

\section{General information on role categories}

The results in Questionnaire 1 show that of the 9 role categories, 3 are identified as belonging to traditional teacher style (TTS) and 6 are reported belonging to modern teacher style (MTS). The 3 role categories identified as belonging to the TTS (sorted in ranking order) are "Source of expertise" (Category I) receiving the TTS-MTS ratio of $57.3 \%-42.7 \%$, "Example of behaviour" (Category IX): $56.3 \%-43.7 \%$, and "Management" (Category II): $50.2 \%-49.7 \%$. The 6 role categories reported belonging to the MTS include: "Assessing \& evaluating" (Category VIII) receiving the MTS-TTS ratio of $76.8 \%-23.2 \%$, "Professional developing" (Category VII): $75.2 \%-24.8 \%$, "Responsibility sharing" (Category V): 74.7\%-25.3\%, "Facilitation of learning" (Category IV): 67.8\%-32.2\%, "Care taking": $55.3 \%-44.7 \%$, and "Source of advice": $54.7 \%-45.3 \%$. Tables 2 and 3 summarize the information.

Table 2. Traditional role categories as identified by EFL school teachers

\begin{tabular}{|l|c|c|}
\hline \multirow{2}{*}{ Role category } & \multicolumn{2}{|c|}{ Teacher style } \\
\cline { 2 - 3 } & TTS (\%) & MTS (\%) \\
\hline I. Source of expertise & 57.3 & 42.7 \\
\hline IX. Example of behaviour & 56.3 & 43.7 \\
\hline II. Management & 50.2 & 49.7 \\
\hline
\end{tabular}

Table 3. Modern role categories as identified by EFL school teachers

\begin{tabular}{|l|c|c|}
\hline \multirow{2}{*}{ Role category } & \multicolumn{2}{|c|}{ Teacher style } \\
\cline { 2 - 3 } & MTS (\%) & TTS (\%) \\
\hline VIII. Assessing \& evaluating & 76.8 & 23.2 \\
\hline VII. Professional developing & 75.2 & 24.8 \\
\hline V. Responsibility sharing & 74.7 & 25.3 \\
\hline IV. Facilitation of learning & 67.8 & 32.2 \\
\hline VI. Care taking & 55.3 & 44.7 \\
\hline III. Source of advice & 54.7 & 45.3 \\
\hline
\end{tabular}




\section{Role item information}

A closer inspection of the teacher roles in the 9 role categories reveals four major findings as follows:

First, Vietnamese EFL school teachers identify more roles as belonging to the MTS than to the TTS. Of the 45 roles in the questionnaire, 12 are identified as belonging to the TTS and 33 as belonging to the MTS. The 12 roles identified as belonging to TTS include: "Teacher as authoritarian" (Item 12): $91.3 \% \quad(\mathrm{~N}=274)$, "Teacher as source of knowledge" (Item 3): 79.7\% ( $\mathrm{N}=239)$,
"Teacher as authority" (Item 13): 76.3\% ( $\mathrm{N}=229$ ), "Teacher as parent" (Item 32): 69\% $(\mathrm{N}=205)$, "Teacher as tutor" (Item 19): 60\% $(\mathrm{N}=180)$, "Teacher as presenter of knowledge" (Item 2): $58.3 \% \quad(\mathrm{~N}=175)$, "Teacher as explainer" (Item 5): 57\% ( $\mathrm{N}=171)$, “Teacher as language model" (Item 45): 57\% ( $\mathrm{N}=171)$, "Teacher as teacher and educator" (Item 1): $56 \%(\mathrm{~N}=168)$, "Teacher as example" (Item 44): $55.7 \%(\mathrm{~N}=167)$, "Teacher as controller" (Item 11): $53.3 \%(\mathrm{~N}=160)$, and "Teacher as manager" (Item 6): $51 \%(\mathrm{~N}=153)$. The information is summarized in Table 4.

Table 4. Roles identified as belonging to the TTS

\begin{tabular}{|c|c|c|c|}
\hline Role & $(\%)$ & Role & $(\%)$ \\
\hline 12. Teacher as authoritarian & 91.3 & 5. Teacher as explainer & 57.0 \\
\hline $\begin{array}{l}\text { 3. Teacher as source of } \\
\text { knowledge }\end{array}$ & 79.7 & 45. Teacher as language model & 57.0 \\
\hline 13. Teacher as authority & 76.3 & 1. Teacher as teacher and educator & 56.0 \\
\hline 32. Teacher as parent & 69.0 & 44. Teacher as example & 55.7 \\
\hline 19. Teacher as tutor & 60.0 & 11. Teacher as controller & 53.3 \\
\hline $\begin{array}{l}\text { 2. Teacher as presenter of } \\
\text { knowledge }\end{array}$ & 58.3 & 6. Teacher as manager & 51.0 \\
\hline
\end{tabular}

The 33 roles reported belonging to the MTS are: "Teacher as syllabus designer" (Item 37): $90.3 \% \quad(\mathrm{~N}=271)$, "Teacher as curriculum evaluator" (Item 41): 90\% $(\mathrm{N}=290)$, "Teacher as textbook developer/ writer" (Item 38): 87.7\% ( $\mathrm{N}=263)$, “Teacher as textbook evaluator" (Item 42): $87.3 \%$ $(\mathrm{N}=262)$, "Teacher as modernizer" (Item 35): $85.7 \%(\mathrm{~N}=257)$, “Teacher as curriculum developer" (Item 36): 83\% (N=265), "Teacher as social worker" (Item 16): 80.3\% ( $\mathrm{N}=241)$, "Teacher as friend" (Item 33): 79\% (N=237), "Teacher as negotiator" (Item 28): 78.7\% $(\mathrm{N}=236)$, "Teacher as learner" (Item 31): $78.3 \%(\mathrm{~N}=235)$, "Teacher as co-participant" (Item 30): $78 \% \quad(\mathrm{~N}=234)$, "Teacher as empowerer" (Item 26): 74\% ( $\mathrm{N}=222)$, "Teacher as inspirer" (Item 23): 72.7\% $(\mathrm{N}=218)$, "Teacher as motivator" (Item 24):
$71.3 \%(\mathrm{~N}=214)$, "Teacher as stimulator" (Item 21): $71 \%(\mathrm{~N}=213)$, "Teacher as enabler" (Item 22): $69.7 \%(\mathrm{~N}=209)$, "Teacher as academic advisor" (Item 18): 68.7\% ( $\mathrm{N}=206)$, "Teacher as researcher" (Item 34): 67.3\% ( $\mathrm{N}=202)$, "Teacher as learning facilitator" (Item 20): $65.7 \%(\mathrm{~N}=197)$, "Teacher as developer of language skills" (Item 4): 64.7\% ( $\mathrm{N}=194)$, "Teacher as responsibility sharer" (Item 29): $64 \%(\mathrm{~N}=192)$, “Teacher as observer" (Item 9): $60.6 \%(\mathrm{~N}=182)$, "Teacher as organizer" (Item 7): 60\% ( $\mathrm{N}=180)$, "Teacher as involver" (Item 25): $59.7 \%(\mathrm{~N}=179)$, "Teacher as planner" (Item 8): 59\% ( $\mathrm{N}=177)$, "Teacher as rapport builder" (Item 27): 59\% ( $\mathrm{N}=177)$, "Teacher as counsellor" (Item 17): $55.7 \%(\mathrm{~N}=167)$, "Teacher as test/exam developer" (Item 39): $55.7 \%(\mathrm{~N}=167)$, “Teacher as monitor" (Item 10): $54 \% \quad(\mathrm{~N}=162)$, “Teacher as learning 
assessor" (Item 14): 53.7\% ( $\mathrm{N}=161)$, “Teacher as learning evaluator" (Item 43): 53.3\% $(\mathrm{N}=160)$, "Teacher as quality controller"
(Item 15): $51.7 \%(\mathrm{~N}=155)$, "Teacher as test/ exam preparer" (Item 40): 51.7\% ( $\mathrm{N}=155)$. Table 5 summarizes the information.

Table 5. Roles identified as belonging to the MTS

\begin{tabular}{|c|c|c|c|}
\hline Role & Percent & Role & Percent \\
\hline 37. Teacher as syllabus designer & 90.3 & 34. Teacher as researcher & 65.7 \\
\hline 41. Teacher as curriculum evaluator & 90.0 & 20. Teacher as learning facilitator & 65.7 \\
\hline $\begin{array}{l}\text { 38. Teacher as textbook developer/ } \\
\text { writer }\end{array}$ & 87.7 & $\begin{array}{l}\text { 4. Teacher as developer of } \\
\text { language skills }\end{array}$ & 64.7 \\
\hline 42. Teacher as textbook evaluator & 87.3 & 29. Teacher as responsibility sharer & 64.0 \\
\hline 35. Teacher as modernizer & 85.7 & 9. Teacher as observer & 60.6 \\
\hline 36. Teacher as curriculum developer & 83.0 & 7. Teacher as organizer & 60.0 \\
\hline 16. Teacher as social worker & 80.3 & 25. Teacher as involver & 59.7 \\
\hline 33. Teacher as friend & 79.0 & 8. Teacher as planner & 59.0 \\
\hline 28. Teacher as negotiator & 78.7 & 27. Teacher as rapport builder & 59.0 \\
\hline 31. Teacher as learner & 78.3 & 17. Teacher as counsellor & 55.7 \\
\hline 30. Teacher as co-participant & 78.0 & 39. Teacher as test/exam developer & 55.7 \\
\hline 26. Teacher as empowerer & 74.0 & 10. Teacher as monitor & 54.0 \\
\hline 23. Teacher as inspirer & 72.7 & 14. Teacher as learning assessor & 53.7 \\
\hline 24. Teacher as motivator & 71.3 & 43. Teacher as learning evaluator & 53.3 \\
\hline 21. Teacher as stimulator & 71.0 & 15. Teacher as quality controller & 51.7 \\
\hline 22. Teacher as enabler & 69.7 & 40. Teacher as test/exam preparer & 51.7 \\
\hline 18. Teacher as academic advisor & 68.7 & & \\
\hline
\end{tabular}

Second, there are role categories in which most or all roles are identified as belonging to the TTS. Here we find "Source of expertise" (Category I) in which $4 / 5$ roles are of the TTS, and "Example of behaviour" (Category IX) in which both roles are of the TTS. In contrast, there are role categories in which most or all roles are reported belonging to the MTS. Here

we find "Management" (Category II) in which $7 / 11$ roles are of the MTS, "Source of advice" (Category III) in which $2 / 3$ roles are of the MTS, "Facilitation of learning" (Category IV) in which all 8 roles are of the MTS, and "Responsibility sharing" (Category V) in which all 4 roles are of the MTS. Tables 6 and 7 summarize the findings described.

Table 6. Role categories having most or all roles of the TTS

\begin{tabular}{|l|c|c|}
\hline \multicolumn{1}{|c|}{ I. Source of expertise } & TTS & MTS \\
\hline 1. Teacher as teacher and educator & $56.0(\mathrm{~N}=168)$ & \\
\hline 2. The teacher as presenter of knowledge & $58.3(\mathrm{~N}=175)$ & \\
\hline 3. Teacher as source of knowledge & $79.7(\mathrm{~N}=239)$ & \\
\hline 4. Teacher as developer of language skills & & $64.7(\mathrm{~N}=194)$ \\
\hline 5. Teacher as explainer & $57.0(\mathrm{~N}=171)$ & \\
\hline IX. Example of bahaviour & & \\
\hline 44. Teacher as example & $55.7(\mathrm{~N}=167)$ & \\
\hline 45. Teacher as language model & $57.0(\mathrm{~N}=171)$ & \\
\hline
\end{tabular}


Table 7. Role categories having most or all roles of the MTS

\begin{tabular}{|c|c|c|c|c|c|}
\hline II. Management & MTS & TTS & IV. Facilitation of learning & MTS & TTS \\
\hline 6. Teacher as manager & & $51.0(\mathrm{~N}=153)$ & $\begin{array}{l}\text { 20. Teacher as learning } \\
\text { facilitator }\end{array}$ & $65.7(\mathrm{~N}=197)$ & \\
\hline 7. Teacher as organizer & $60.0(\mathrm{~N}=180)$ & & 21. Teacher as stimulator & $71.0(\mathrm{~N}=213)$ & \\
\hline 8. Teacher as planner & $59.0(\mathrm{~N}=177)$ & & 22. Teacher as enabler & $69.7(\mathrm{~N}=209)$ & \\
\hline 9. Teacher as observer & $60.6(\mathrm{~N}=182)$ & & 23. Teacher as inspirer & $72.7(\mathrm{~N}=218)$ & \\
\hline 10. Teacher as monitor & $54.0(\mathrm{~N}=162)$ & & 24. Teacher as motivator & $71.3(\mathrm{~N}=214)$ & \\
\hline 11. Teacher as controller & & $53.3(\mathrm{~N}=160)$ & 25. Teacher as involver & $59.7(\mathrm{~N}=179)$ & \\
\hline 12. Teacher as authoritarian & & $91.3(\mathrm{~N}=274)$ & 26. Teacher as empowerer & $74.0(\mathrm{~N}=222)$ & \\
\hline 13. Teacher as authority & & $76.3(\mathrm{~N}=229)$ & 27. Teacher as rapport builder & $59.0(\mathrm{~N}=177)$ & \\
\hline 14. Teacher as learning assessor & $53.7(\mathrm{~N}=161)$ & & \multicolumn{3}{|l|}{ V. Responsibility sharing } \\
\hline 15. Teacher as quality controller & $51.7(\mathrm{~N}=155)$ & & 28. Teacher as negotiator & $78.7(\mathrm{~N}=236)$ & \\
\hline 16. Teacher as social worker & $80.3(\mathrm{~N}=241)$ & & $\begin{array}{l}\text { 29. Teacher as responsibility } \\
\text { sharer }\end{array}$ & $64.0(\mathrm{~N}=192)$ & \\
\hline \multicolumn{3}{|l|}{ III. Source of advice } & 30. Teacher as co-participant & $78.0(\mathrm{~N}=234)$ & \\
\hline 17. Teacher as counsellor & $55.7(\mathrm{~N}=167)$ & & 31. Teacher as learner & $78.3(\mathrm{~N}=235)$ & \\
\hline 18. Teacher as academic advisor & $68.7(\mathrm{~N}=206)$ & & & & \\
\hline 19. Teacher as tutor & & $60.0(\mathrm{~N}=180)$ & & & \\
\hline
\end{tabular}

Third, most of the roles which are suggested by researchers such as Breen \& Candlin (1980), Nunan (1991), Tudor (1993, 1996), De Lopez (1994), Widdowson (1999), Hedge (2000), Graves (2005), Harmer (2005), Keller (2011) and others as belonging to the learner-centred approach are identified as belonging to the MTS. Here we find such roles as "Teacher as counsellor" (Item 17), "Teacher as academic advisor" (Item 18), "Teacher as facilitator" (Item 20), "Teacher as stimulator" (Item 21), "Teacher as empowerer" (Item 26), "Teacher as negotiator" (Item 28), "Teacher as responsibility sharer" (Item 29), "Teacher as curriculum developer" (Item 36), "Teacher as syllabus designer" (Item 37), "Teacher as material/textbook developer/writer" (Item 38), "Teacher as curriculum evaluator" (Item 41), and "Teacher as material/textbook evaluator" (Item 42). In contrast, most of the roles which are said to belong to the teachercentred approach are reported belonging to the TTS. Here we find such roles as "Teacher as source of knowledge" (Item 3), "Teacher as authoritarian" (Item 12), "Teacher as authority" (Item 13), and "Teacher as example" (Item 44).
Finally, a number of teacher roles which have not yet been classified in the literature as belonging to either of the two teacher styles are perceived by the EFL school teachers as belonging to the MTS. But a closer look at these teacher roles will reveal that they can be of the TTS as well. Here we find "Teacher as organizer" (Items 7), “Teacher as planner" (Item 8), “Teacher as assessor" (Item 14), "Teacher as quality controller" (Item 15), "Teacher as rapport builder" (Item 27), "Teacher as researcher" (Item 34), "Teacher as test/exam developer" (Item 39), "Teacher as test/exam preparer" (Item 40), and others.

Objective 2: Findings relating to how Vietnamese EFL school teachers rate the importance of teacher roles through teacher role-pertained responsibilities

Question 2: How do Vietnamese EFL school teachers rate the importance of teacher roles through teacher rolepertained responsibilities? 


\section{EFL teachers' rating of role categories}

Overall it can be said that most of the role categories are very highly rated by Vietnamese EFL school teachers. Of the 9 role categories, "Facilitation of learning" (Category IV) tops the list: of the 8 teacher role-pertained responsibilities in this category $(\mathrm{N}=2,400)$, "Not at all important" and "Not very important" take up only $0.4 \%$ and $3.5 \%$ respectively, while "Important" accounts for 24\%, "Very important" 36.1\%, and "Totally important" $35.8 \%$, with the mean of 4.03 . Ranked second is "Source of expertise" (Category I): of the 5 teacher role-pertained responsibilities in this category $(\mathrm{N}=1,500)$, "Not at all important" and "Not very important" take up only $0.8 \%$ and $6.2 \%$ respectively, while "Important" accounts for $30.1 \%$, "Very important" $27.6 \%$, and "Totally important" $35 \%$, with the mean of 3.89. Ranked third is "Example of behaviour" (Category IX): of the 2 teacher role-pertained responsibilities in this category $(\mathrm{N}=600)$, "Not at all important" and "Not very important" take up only $2.3 \%$ and $5.5 \%$ respectively, while "Important" accounts for $31.5 \%$, "Very important" $35.3 \%$, and "Totally important" $25.3 \%$, with the mean of 3.76. Ranked fourth is "Management" (Category II): of the 11 teacher role-pertained responsibilities in this category $(\mathrm{N}=3,300)$, "Not at all important" takes up only $2.8 \%$, "Not very important" $9.8 \%$, while "Important" accounts for 30.4\%, "Very important" 35.7\%, and "Totally important" $21 \%$, with the mean of 3.62. "Professional developing" (Category VII), "Source of advice" (Category III) and "Assessing \& evaluating" (Category VIII) are roughly equally rated: of the 7 teacher role-pertained responsibilities in the category of "Professional developing" $(\mathrm{N}=2,100)$, "Not at all important" takes up 6.4\%, "Not very important" $13.8 \%$, while "Important" accounts for 31.6\%, "Very important" $29.6 \%$, and "Totally important" $18.6 \%$, with the mean of 3.4 ; of the 3 teacher role-pertained responsibilities in the category of "Source of advice" ( $=900)$, "Not at all important" takes up only $2.1 \%$, "Not very important" $11.5 \%$, while "Important" accounts for $43.1 \%$, "Very important" $31.7 \%$, and "Totally important" $11.1 \%$, with the mean of 3.38; and of the 3 teacher role-pertained responsibilities in the category of "Assessing \& evaluating" $(\mathrm{N}=900)$, "Not at all important" takes up only 3\%, "Not very important" $13.5 \%$, while "Important" accounts for 38.8\%, "Very important" $32.6 \%$, and "Totally important" $12 \%$, with the mean of 3.37 . "Responsibility sharing" (Category V) and "Care taking" (Category VI) are at the bottom of the list: of the 4 teacher role-pertained responsibilities in the category of "Responsibility sharing" $(\mathrm{N}=1,200), 6.7 \%$ of the respondents rated it as "Not at all important", $13.3 \%$ as "Not very important", while $36.5 \%$ rated it as "Important", $30.1 \%$ as "Very important", and $12.9 \%$ as "Totally important", with the mean of 3.29. And of the 2 teacher role-pertained responsibilities in the category of "Care taking" $(\mathrm{N}=600), 14.8 \%$ of the respondents rated it as "Not at all important", $25.1 \%$ as "Not very important", while $34.3 \%$ rated as "Important", and $21.3 \%$ as "Very important", while only $4.1 \%$ rated it as "Totally important", with the mean of 2.75 . Table 8 provides a summary of the reported information.

Table 8. EFL teachers' rating of teacher role categories

\begin{tabular}{|l|l|l|l|l|l|l|}
\hline \multicolumn{1}{|c|}{ Role category } & $\begin{array}{c}\text { Not at all } \\
\text { important }\end{array}$ & $\begin{array}{c}\text { Not very } \\
\text { important }\end{array}$ & Important & $\begin{array}{c}\text { Very } \\
\text { important }\end{array}$ & $\begin{array}{c}\text { Totally } \\
\text { important }\end{array}$ & Mean \\
\hline IV. Facilitation of learning & 0.4 & 3.5 & 24.0 & 36.1 & 35.8 & 4.03 \\
\hline I. Source of expertise & 0.8 & 6.2 & 30.1 & 27.6 & 35.0 & 3.89 \\
\hline IX. Example of behaviour & 2.3 & 5.5 & 31.5 & 35.3 & 25.3 & 3.76 \\
\hline II. Management & 2.8 & 9.8 & 30.4 & 35.7 & 21.0 & 3.62 \\
\hline
\end{tabular}




\begin{tabular}{|l|l|l|l|l|l|l|}
\hline \multicolumn{1}{|c|}{ Role category } & $\begin{array}{c}\text { Not at all } \\
\text { important }\end{array}$ & $\begin{array}{c}\text { Not very } \\
\text { important }\end{array}$ & Important & $\begin{array}{c}\text { Very } \\
\text { important }\end{array}$ & $\begin{array}{c}\text { Totally } \\
\text { important }\end{array}$ & Mean \\
\hline $\begin{array}{l}\text { VII. Professional } \\
\text { developing }\end{array}$ & 6.4 & 13.8 & 31.6 & 29.6 & 18.6 & 3.40 \\
\hline III. Source of advice & 2.1 & 11.5 & 43.1 & 31.7 & 11.1 & 3.38 \\
\hline $\begin{array}{l}\text { VIII Assessing \& } \\
\text { evaluating }\end{array}$ & 3.0 & 13.5 & 38.8 & 32.6 & 12.0 & 3.37 \\
\hline V. Responsibility sharing & 6.7 & 13.3 & 36.5 & 31.1 & 12.9 & 3.29 \\
\hline VI. Care taking & 14.8 & 25.1 & 34.3 & 21.5 & 4.1 & 2.75 \\
\hline
\end{tabular}

\section{EFL teachers' rating of traditional teacher roles}

Cutting across the teacher style dimension (Questionnaire 1), more significant findings can be found when we look at how Vietnamese EFL teachers rate the importance of teacher roles through the traditional teacher role (TTR)-pertained responsibilities in this Questionnaire 2. It is expected that those teacher roles that were identified as belonging to the TTS would receive low ratings from the participants. But the results prove to be the opposite: of the 12 responsibilities pertaining to the 12 teacher roles which were identified as belonging to the TTS, 4 (33.3\%) receive high ratings, $5(41.6 \%)$ receive medium ratings, and $3(25 \%)$ receive low ratings.

The 4 TTR-pertained responsibilities receiving high ratings are: "Teacher as teacher and educator" (Item 1) in which "Not at all important" receives no rating, "Not very important" takes up only $1 \%(\mathrm{~N}=3)$, "Important" accounts for $18.6 \%(\mathrm{~N}=56)$, "Very important" $21.7 \%(\mathrm{~N}=65)$, and "Totally important" 58.6\% $(\mathrm{N}=176)$, with the mean of 4.38 ; "Teacher as presenter of knowledge" (Item 2) in which, like Item 1, "Not at all important" receives no rating, "Not very important" takes up only $2.3 \% \quad(\mathrm{~N}=7)$, “Important" $30.3 \% \quad(\mathrm{~N}=91)$, "Very important" 27.3\% (N=82), and "Totally important" $40 \%(\mathrm{~N}=120)$, with the mean of 4.05; "Teacher as manager" (Item 6) in which, like Items 1 and 2, "Not at all important" receives no rating, "Not very important" takes up only $1.7 \% \quad(\mathrm{~N}=5)$, "Important" $21.6 \%$ $(\mathrm{N}=65)$, while "Very important" accounts for $43.3 \%(\mathrm{~N}=130)$, and "Totally important" $33.3 \%(\mathrm{~N}=100)$, with the mean of 4.08 ; and "Teacher as example" (Item 44) in which, like Items 1, 2, and 3, "Not at all important" receives no rating, "Not very important" takes up only $3.7 \%(\mathrm{~N}=11)$, "Important" accounts for $29.6 \%$ $(\mathrm{N}=89)$, "Very important" $34.3 \%(\mathrm{~N}=103)$, and "Totally important" $32.3 \%(\mathrm{~N}=97)$, with the mean of 3.95 .

The 5 TTR-pertained responsibilities receiving medium ratings include: "Teacher as language model" (Item 44) in which "Not at all important" takes up $4.7 \%(\mathrm{~N}=14)$, "Not very important" $7.3 \%(\mathrm{~N}=22)$, "Important" $33.3 \% \quad(\mathrm{~N}=100)$, "Very important" 36.3\% $(\mathrm{N}=109)$, and "Totally important" $18.3 \%$ $(\mathrm{N}=55)$, with the mean of 3.56 ; "Teacher as source of knowledge" (Item 3) in which "Not at all important" receives no rating, "Not very important" takes up $10.3 \%$ $(\mathrm{N}=31)$, "Important" 40.6\% ( $\mathrm{N}=122)$, "Very important" $33.3 \% \quad(\mathrm{~N}=100)$, and "Totally important" $15.7 \%(\mathrm{~N}=47)$, with the mean of 3.54; "Teacher as tutor" (Item 19) in which "Not at all important" takes up only $2 \%(\mathrm{~N}=6)$, "Not very important" accounts for $11.6 \%$ $(\mathrm{N}=35)$, "Important" 39.3\% ( $\mathrm{N}=118)$, "Very important" $34.6 \% \quad(\mathrm{~N}=104)$, and "Totally important" $12.3 \%(\mathrm{~N}=55)$, with the mean of 3.44; "Teacher as controller" (Item 11) in which "Not at all important" takes up 4.6\% $(\mathrm{N}=14)$, "Not very important" $18.3 \%(\mathrm{~N}=55)$, "Important" 27.3\% (N=82), "Very important" $36.3 \%(\mathrm{~N}=109)$, and "Totally important" 
$13.3 \%(\mathrm{~N}=40)$, with the mean of 3.35 ; and "Teacher as explainer" (Item 5) in which "Not at all important" takes up $4.3 \%(\mathrm{~N}=13)$, "Not very important" $17.6 \%(\mathrm{~N}=53)$, "Important" $44.7 \% \quad(\mathrm{~N}=134)$, "Very important" 29.3\% $(\mathrm{N}=88)$, and "Totally important" $4 \%(\mathrm{~N}=12)$, with the mean of 3.11 .

And the 3 TTR-pertained responsibilities receiving low ratings consist of "Teacher as authoritarian" (Item 12) in which "Not at all important" accounts for $6.7 \%(\mathrm{~N}=20)$, "Not very important" $28.6 \%(\mathrm{~N}=86)$, "Important" $41 \%(\mathrm{~N}=123)$, "Very important" $20.3 \%(\mathrm{~N}=61)$, and "Totally important" $3.3 \%(\mathrm{~N}=10)$, with the mean of 2.85; "Teacher as authority" (Item 13) in which "Not at all important" takes up 13\% $(\mathrm{N}=39)$, "Not very important" $25.3 \%(\mathrm{~N}=76)$, "Important" 37.6\% (N=113), "Very important" $20.3 \%(\mathrm{~N}=61)$, and "Totally important" $3.7 \%$ $(\mathrm{N}=11)$, with the mean of 2.76; and "Teacher as parent" (Item 32) in which "Not at all important" takes up $27.7 \%(\mathrm{~N}=83)$, "Not very important" $34.6 \%(\mathrm{~N}=104)$, "Important" 21.6\% ( $\mathrm{N}=65)$, "Very important" $14.3 \%(\mathrm{~N}=43)$, and "Totally important" accounts for only $1.7 \%(\mathrm{~N}=5)$, with the mean of 2.28. Table 9 summarizes the information described.

Table 9. EFL teachers' rating of TTR-pertained responsibilities

\begin{tabular}{|c|c|c|c|c|c|c|}
\hline $\begin{array}{c}\text { (Responsibilities pertaining to) } \\
\text { teacher } \text { roles }^{2}\end{array}$ & $\begin{array}{l}\text { Not at all } \\
\text { important }\end{array}$ & $\begin{array}{c}\text { Not very } \\
\text { important }\end{array}$ & Important & $\begin{array}{c}\text { Very } \\
\text { important }\end{array}$ & $\begin{array}{c}\text { Totally } \\
\text { important }\end{array}$ & Mean \\
\hline \multicolumn{7}{|c|}{ High rating } \\
\hline 1. Teacher as teacher and educator & & $1.0(\mathrm{~N}=3)$ & $18.6(\mathrm{~N}=56)$ & $21.7(\mathrm{~N}=65)$ & $58.6(\mathrm{~N}=176)$ & 4.38 \\
\hline 6. Teacher as manager & & $1.7(\mathrm{~N}=5)$ & $21.6(\mathrm{~N}=65)$ & $43.3(\mathrm{~N}=130)$ & $33.3(\mathrm{~N}=100)$ & 4.08 \\
\hline $\begin{array}{l}\text { 2. Teacher as presenter of } \\
\text { knowledge }\end{array}$ & & $2.3(\mathrm{~N}=7)$ & $30.3(\mathrm{~N}=91)$ & $27.3(\mathrm{~N}=82)$ & $40.0(\mathrm{~N}=120)$ & 4.05 \\
\hline 44. Teacher as example & & $3.7(\mathrm{~N}=11)$ & $29.6(\mathrm{~N}=89)$ & $34.3(\mathrm{~N}=103)$ & $32.3(\mathrm{~N}=97)$ & 3.95 \\
\hline \multicolumn{7}{|c|}{ Medium rating } \\
\hline 45. Teacher as language model & $4.7(\mathrm{~N}=14)$ & $7.3(\mathrm{~N}=22)$ & $33.3(\mathrm{~N}=100)$ & $36.3(\mathrm{~N}=109)$ & $18.3(\mathrm{~N}=55)$ & 3.56 \\
\hline 3. Teacher as source of knowledge & & $10.3(\mathrm{~N}=31)$ & $40.6(\mathrm{~N}=122)$ & $33.3(\mathrm{~N}=100)$ & $15.7(\mathrm{~N}=47)$ & 3.54 \\
\hline 19. Teacher as tutor & $2.0(\mathrm{~N}=6)$ & $11.6(\mathrm{~N}=35)$ & $39.3(\mathrm{~N}=118)$ & $34.6(\mathrm{~N}=104)$ & $12.3(\mathrm{~N}=37)$ & 3.44 \\
\hline 11. Teacher as controller & $4.6(\mathrm{~N}=14)$ & $18.3(\mathrm{~N}=55)$ & $27.3(\mathrm{~N}=82)$ & $36.3(\mathrm{~N}=109)$ & $13.3(\mathrm{~N}=40)$ & 3.35 \\
\hline 5. Teacher as explainer & $4.3(\mathrm{~N}=13)$ & $17.6(\mathrm{~N}=53)$ & $44.7(\mathrm{~N}=134)$ & $29.3(\mathrm{~N}=88)$ & $4.0(\mathrm{~N}=12)$ & 3.11 \\
\hline \multicolumn{7}{|c|}{ Low rating } \\
\hline 12. Teacher as authoritarian & $6.7(\mathrm{~N}=20)$ & $28.6(\mathrm{~N}=86)$ & $41.0(\mathrm{~N}=123)$ & $20.3(\mathrm{~N}=61)$ & $3.3(\mathrm{~N}=10)$ & 2.85 \\
\hline 13. Teacher as authority & $13.0(\mathrm{~N}=39)$ & $25.3(\mathrm{~N}=76)$ & $37.6(\mathrm{~N}=113)$ & $20.3(\mathrm{~N}=61)$ & $3.7(\mathrm{~N}=11)$ & 2.76 \\
\hline 32. Teacher as parent & $27.7(\mathrm{~N}=83)$ & $34.6(\mathrm{~N}=104)$ & $21.6(\mathrm{~N}=65)$ & $14.3(\mathrm{~N}=43)$ & $1.7(\mathrm{~N}=5)$ & 2.28 \\
\hline
\end{tabular}

\section{${ }^{1}$ EFL teachers' rating of modern teacher roles}

Turning to how Vietnamese EFL teachers rate modern teacher roles (MTR), it is of interest of note that of the 33 pertained responsibilities whose roles were identified as belonging to the MTS, 8 (24.2\%) receive very high ratings, $10(30.3 \%)$ receive high ratings, 12 receive medium ratings $(36.3 \%)$, and 3 (9\%) receive low ratings.

1 It should be noted that the responsibilities pertaining to the teacher roles should be presented in this column. For reason of space, however, only teacher roles are presented.
The 8 MTR-pertained responsibilities receiving very high ratings are: "Teacher as stimulator" (Item 21) in which "Not at all important" receives no rating, "Not very important" takes up 1.7\% (N=5), "Important" $13 \% \quad(\mathrm{~N}=39)$, "Very important" $25.6 \%$ $(\mathrm{N}=77)$, and "Totally important" $59.6 \%$ $(\mathrm{N}=179)$, with the mean of 4.43 ; "Teacher as developer of language skills" (Item 4) in which "Not at all important" receives no rating, "Not very important" takes up $0.7 \%$ $(\mathrm{N}=2)$, "Important" 16.3\% $(\mathrm{N}=49)$, "Very important" $26.3 \% \quad(\mathrm{~N}=79)$, and "Totally 
important" 56.6\% ( $\mathrm{N}=170)$, with the mean of 4.39; "Teacher as motivator" (Item 24) in which "Not at all important" receives no rating, "Not very important" accounts for $1.3 \% \quad(\mathrm{~N}=4)$, “Important" $13.6 \% \quad(\mathrm{~N}=41)$, "Very important" 36.6\% (N=110), and "Totally important" $48.3 \%(\mathrm{~N}=145)$, with the mean of 4.32; "Teacher as involver" (Item 25 ) in which "Not at all important" receives no rating, "Not very important" accounts for $1.7 \% \quad(\mathrm{~N}=5)$, “Important" $15.7 \% \quad(\mathrm{~N}=47)$, "Very important" $38.6 \% \quad(\mathrm{~N}=116)$, and "Totally important" 44\% (N=132), with the mean of 4.25; "Teacher as organizer" (Item 7) in which "Not at all important" receives no rating, "Not very important" accounts for $1.3 \%(\mathrm{~N}=4)$, "Important" $18.6 \%(\mathrm{~N}=56)$, "Very important" $41.7 \% \quad(\mathrm{~N}=125)$, and "Totally important" $38.3 \%(\mathrm{~N}=115)$, with the mean of 4.17; "Teacher as planner" (Item 8) in which "Not at all important" receives no rating, "Not very important" takes up 2.7\% $(\mathrm{N}=8)$, "Important" $17.3 \% \quad(\mathrm{~N}=52)$, "Very important" $41.7 \% \quad(\mathrm{~N}=125)$, and "Totally important" $38.3 \%(\mathrm{~N}=115)$, with the mean of 4.16; "Teacher as inspirer" (Item 23) in which "Not at all important" receives no rating, "Not very important" accounts for $3.3 \%(\mathrm{~N}=10)$, "Important" 18.6\% (N=56), "Very important" $36.3 \%(\mathrm{~N}=109)$, and "Totally important" $41.7 \%(\mathrm{~N}=125)$, with the mean of 4.16 ; and "Teacher as enabler" (Item 22) in which "Not at all important" receives no rating, "Not very important" takes up 2.7\% (N=8), "Important" $26.3 \% \quad(\mathrm{~N}=79)$, "Very important" $25.6 \%$ $(\mathrm{N}=77)$, and "Totally important" $33.3 \%$ $(\mathrm{N}=110)$, with the mean of 4.02 . Table 10 summarizes the information.

Table 10. MTR-pertained responsibilities receiving very high ratings

\begin{tabular}{|l|c|c|c|c|c|r|}
\hline $\begin{array}{c}\text { Responsibilities pertaining to teacher } \\
\text { roles }\end{array}$ & $\begin{array}{c}\text { Not at all } \\
\text { important }\end{array}$ & $\begin{array}{c}\text { Not very } \\
\text { important }\end{array}$ & Important & $\begin{array}{c}\text { Very } \\
\text { important }\end{array}$ & $\begin{array}{c}\text { Totally } \\
\text { important }\end{array}$ & Mean \\
\hline 21. Teacher as stimulator & & $1.7(\mathrm{~N}=5)$ & $13.0(\mathrm{~N}=39)$ & $25.6(\mathrm{~N}=77)$ & $59.6(\mathrm{~N}=179)$ & 4.43 \\
\hline 4. Teacher as developer of language skills & & $0.7(\mathrm{~N}=2)$ & $16.3(\mathrm{~N}=49)$ & $26.3(\mathrm{~N}=79)$ & $56.6(\mathrm{~N}=170)$ & 4.39 \\
\hline 24. Teacher as motivator & & $1.3(\mathrm{~N}=4)$ & $13.6(\mathrm{~N}=41)$ & $36.6(\mathrm{~N}=110)$ & $48.3(\mathrm{~N}=145)$ & 4.32 \\
\hline 25. Teacher as involver & & $1.7(\mathrm{~N}=5)$ & $15.7(\mathrm{~N}=47)$ & $38.6(\mathrm{~N}=116)$ & $44.0(\mathrm{~N}=132)$ & 4.25 \\
\hline 7. Teacher as organizer & & $1.3(\mathrm{~N}=4)$ & $18.6(\mathrm{~N}=56)$ & $41.7(\mathrm{~N}=125)$ & $38.3(\mathrm{~N}=115)$ & 4.17 \\
\hline 8. Teacher as planner & & $2.7(\mathrm{~N}=8)$ & $17.3(\mathrm{~N}=52)$ & $41.7(\mathrm{~N}=125)$ & $38.3(\mathrm{~N}=115)$ & 4.16 \\
\hline 23. Teacher as inspirer & & $3.3(\mathrm{~N}=10)$ & $18.6(\mathrm{~N}=56)$ & $36.3(\mathrm{~N}=109)$ & $41.7(\mathrm{~N}=125)$ & 4.16 \\
\hline 22. Teacher as enabler & & $2.7(\mathrm{~N}=8)$ & $26.3(\mathrm{~N}=79)$ & $37.6(\mathrm{~N}=113)$ & $33.3(\mathrm{~N}=100)$ & 4.02 \\
\hline
\end{tabular}

The 10 MTR-pertained responsibilities receiving high ratings include: "Teacher as test/ exam developer" (Item 39) in which "Not at all important" accounts for $2.3 \%(\mathrm{~N}=7)$, "Not very important" 4\% ( $\mathrm{N}=12)$, "Important" 25.3\% $(\mathrm{N}=76)$, "Very important" 38.6\% ( $=116)$, and "Totally important" $29.7 \%(\mathrm{~N}=89)$, with the mean of 3.89; "Teacher as monitor (Item $10)$ in which "Not at all important" accounts for $0.7 \%(\mathrm{~N}=2)$, "Not very important" $2.3 \%$ $(\mathrm{N}=7)$, "Important" 31.6\% (N=95), "Very important" $39 \% \quad(\mathrm{~N}=117)$, and "Totally important" $26.3 \%(\mathrm{~N}=79)$, with the mean of
3.88; "Teacher as rapport builder" (Item 27) in which "Not at all important" and "Not very important" receive no rating, "Important" takes up 35.3\% ( $=106)$, "Very important" $41.3 \%(\mathrm{~N}=124)$, and "Totally important" $23.3 \%(\mathrm{~N}=70)$, with the mean of 3.88 ; "Teacher as learning facilitator" (Item 20) in which "Not at all important" and "Not very important" take up $1 \%(\mathrm{~N}=3)$ and $3 \%(\mathrm{~N}=9)$ respectively, "Important" accounts for 31\% $(\mathrm{N}=93)$, "Very important" 39.6\% ( $\mathrm{N}=119)$, and "Totally important" $25.4 \%(\mathrm{~N}=76)$, with the mean of 3.85 ; "Teacher as observer" (Item 
9) in which "Not at all important" and "Not very important" account for $0.7 \% \quad(\mathrm{~N}=2)$ and $4.3 \%(\mathrm{~N}=13)$ respectively, "Important" takes up 29.3\% ( $=88)$, "Very important" $43.6 \%(\mathrm{~N}=131)$, and "Totally important" $22 \%$ $(\mathrm{N}=66)$, with the mean of 3.82 ; "Teacher as text/exam preparer" (Item 40) in which "Not at all important" and "Not very important" account for $0.7 \%(\mathrm{~N}=2)$ and $4.6 \%(\mathrm{~N}=13)$ respectively, "Important" takes up 30\% $(\mathrm{N}=90)$, "Very important" 37.6\% ( $=113)$, and "Totally important" $26 \%(\mathrm{~N}=78)$, with the mean of 3.82 ; "Teacher as quality controller" (Item 15) in which "Not at all important" receives no rating, "Not very important" takes up 3.3\% $(\mathrm{N}=10)$, "Important" 32.3\% $(\mathrm{N}=97)$, "Very important" $45.6 \% \quad(\mathrm{~N}=137)$, and "Totally important" $18.7 \%(\mathrm{~N}=56)$, with the mean of 3.80; "Teacher as learning assessor"
(Item 14) in which "Not at all important" and "Not very important" take up $1.3 \%(\mathrm{~N}=4)$ and $3.7 \%(\mathrm{~N}=11)$ respectively, "Important" 35.6\% $(\mathrm{N}=107)$, "Very important" 33\% ( $\mathrm{N}=99)$, and "Totally important" $26.3 \%(\mathrm{~N}=78)$, with the mean of 3.79; "Teacher as researcher" (Item 34) in which "Not at all important" receives no rating, "Not very important" takes up 4.3\% $(\mathrm{N}=13)$, "Important" accounts for $35.3 \%$ $(\mathrm{N}=106)$, "Very important" 38\% ( $\mathrm{N}=114)$, and "Totally important" $22.3 \%(\mathrm{~N}=67)$, with the mean of 3.78; and "Teacher as counsellor" (Item 17) in which "Not at all important" and "Not very important" receive no rating, "Important" takes up 43.3\% (N=130), "Very important" $40.3 \% \quad(\mathrm{~N}=121)$, and "Totally important" $16.3 \%(\mathrm{~N}=49)$, with the mean of 3.73. Table 11 provides the reported information.

Table 11. MTR-pertained responsibilities receiving high ratings

\begin{tabular}{|c|c|c|c|c|c|c|}
\hline $\begin{array}{c}\text { Responsibilities pertaining to teacher } \\
\text { roles }\end{array}$ & $\begin{array}{l}\text { Not at all } \\
\text { important }\end{array}$ & $\begin{array}{l}\text { Not very } \\
\text { important }\end{array}$ & Important & Very important & $\begin{array}{l}\text { Totally } \\
\text { important }\end{array}$ & Mean \\
\hline 39. Teacher as test/exam developer & $2.3(\mathrm{~N}=7)$ & $4.0(\mathrm{~N}=12)$ & $25.3(\mathrm{~N}=76)$ & $38.6(\mathrm{~N}=116)$ & $29.7(\mathrm{~N}=89)$ & 3.89 \\
\hline 10. Teacher as monitor & $0.7(\mathrm{~N}=2)$ & $2.3(\mathrm{~N}=7)$ & $31.6(\mathrm{~N}=95)$ & $39.0(\mathrm{~N}=117)$ & $26.3(\mathrm{~N}=79)$ & 3.88 \\
\hline 27. Teacher as rapport builder & & & $35.3(\mathrm{~N}=106)$ & $41.3(\mathrm{~N}=124)$ & $23.3(\mathrm{~N}=70)$ & 3.88 \\
\hline 20. Teacher as learning facilitator & $1.0(\mathrm{~N}=3)$ & $3.0(\mathrm{~N}=9)$ & $31.0(\mathrm{~N}=93)$ & $39.6(\mathrm{~N}=119)$ & $25.4(\mathrm{~N}=76)$ & 3.85 \\
\hline 9. Teacher as observer & $0.7(\mathrm{~N}=2)$ & $4.3(\mathrm{~N}=13)$ & $29.3(\mathrm{~N}=88)$ & $43.6(\mathrm{~N}=131)$ & $22.0(\mathrm{~N}=66)$ & 3.82 \\
\hline 40. Teacher as test/exam preparer & $1.7(\mathrm{~N}=5)$ & $4.6(\mathrm{~N}=14)$ & $30.0(\mathrm{~N}=90)$ & $37.6(\mathrm{~N}=113)$ & $26.0(\mathrm{~N}=78)$ & 3.82 \\
\hline 15. Teacher as quality controller & & $3.3(\mathrm{~N}=10)$ & $32.3(\mathrm{~N}=97)$ & $45.6(\mathrm{~N}=137)$ & $18.7(\mathrm{~N}=56)$ & 3.80 \\
\hline 14. Teacher as learning assessor & $1.3(\mathrm{~N}=4)$ & $3.7(\mathrm{~N}=11)$ & $35.6(\mathrm{~N}=107)$ & $33.0(\mathrm{~N}=99)$ & $26.3(\mathrm{~N}=79)$ & 3.79 \\
\hline 34. Teacher as researcher & & $4.3(\mathrm{~N}=13)$ & $35.3(\mathrm{~N}=106)$ & $38.0(\mathrm{~N}=114)$ & $22.3(\mathrm{~N}=67)$ & 3.78 \\
\hline 17. Teacher as counsellor & & & $43.3(\mathrm{~N}=130)$ & $40.3(\mathrm{~N}=121)$ & $16.3(\mathrm{~N}=49)$ & 3.73 \\
\hline
\end{tabular}

The 12 MTR-pertained responsibilities that receive medium ratings consist of "Teacher as learning evaluator" (Item 43) in which "Not at all important" takes up $0.6 \%$ $(\mathrm{N}=2)$, "Not very important" accounts for $6.7 \%(\mathrm{~N}=20)$, “Important" $36.6 \%(\mathrm{~N}=110)$, "Very important" $40.3 \% \quad(\mathrm{~N}=121)$, and "Totally important" $15.6 \% \quad(\mathrm{~N}=47)$, with the mean of 3.64; "Teacher as responsibility sharer" (Item 29) in which "Not at all important" takes up 2\% (N=6), "Not very important" 4.7\% (N=14), "Important" 38.3\% $(\mathrm{N}=115)$, "Very important" $39.3 \%(\mathrm{~N}=118)$, and "Totally important" $15.7 \%(\mathrm{~N}=47)$, with the mean of 3.62 ; "Teacher as modernizer" (Item 35) in which "Not at all important" takes up 2.3\% $(\mathrm{N}=7)$, "Not very important" 4.6\% ( $\mathrm{N}=14)$, "Important" 39.3\% ( $\mathrm{N}=118)$, "Very important" $37.3 \% \quad(\mathrm{~N}=112)$, and "Totally important" $16.3 \%(\mathrm{~N}=49)$, with the mean of 3.61; "Teacher as learner" (Item 31 ) in which "Not at all important" takes 
up 1.3\% (N=4), "Not very important" 9.3\% $(\mathrm{N}=28)$, "Important" 36.6\% ( $\mathrm{N}=110)$, "Very important" $35.2 \% \quad(\mathrm{~N}=102)$, and "Totally important" $17.3 \%(\mathrm{~N}=52)$, with the mean of 3.58; "Teacher as co-participant/team member" (Item 30) in which "Not at all important" takes up 3.3\% (N=10), "Not very important" 7.7\% ( $\mathrm{N}=23)$, "Important" 42\% $(\mathrm{N}=126)$, "Very important" $31.6 \%(\mathrm{~N}=95)$, and "Totally important" $16.3 \%(\mathrm{~N}=46)$, with the mean of 3.48; "Teacher as curriculum developer" (Item 36) in which "Not at all important" takes up 3.7\% (N=11), "Not very important" 20.3\% (N=61), "Important" 30.6\% $(\mathrm{N}=92)$, "Very important" 26.7\% ( $\mathrm{N}=80)$, and "Totally important" $18.6 \%(\mathrm{~N}=56)$, with the mean of 3.36; "Teacher as empowerer" (Item 26) in which "Not at all important" takes up $2.7 \%(\mathrm{~N}=8)$, "Not very important" $14.6 \%(\mathrm{~N}=44)$, "Important" 38.6\% ( $\mathrm{N}=116)$, "Very important" $32.7 \%(\mathrm{~N}=98)$, and "Totally important" $11.3 \%(\mathrm{~N}=34)$, with the mean of 3.35; "Teacher as curriculum evaluator" (Item 41) in which "Not at all important" takes up 6.7\% $(\mathrm{N}=20)$, "Not very important" $10 \%(\mathrm{~N}=30)$, "Important" 38.3\% ( $=115)$, "Very important" $36.3 \% \quad(\mathrm{~N}=109)$, and
"Totally important" 8.6\% ( $=26)$, with the mean of 3.30; "Teacher as friend" (Item 33) in which "Not at all important" takes up 2\% $(\mathrm{N}=6)$, "Not very important" $15.6 \%(\mathrm{~N}=47)$, "Important" 47\% (N=141), "Very important" $28.6 \%(\mathrm{~N}=86)$, and "Totally important" $6.7 \%$ $(\mathrm{N}=20)$ with the mean of 3.22; "Teacher as social worker" (Item 16) in which "Not at all important" takes up 4.6\% ( $\mathrm{N}=14)$, "Not very important" 16.3\% (N=49), "Important" 42.6\% $(\mathrm{N}=128)$, "Very important" 28.7\% ( $\mathrm{N}=86)$, and "Totally important" $7.6 \%(\mathrm{~N}=23)$, with the mean of 3.18; "Teacher as textbook evaluator" (Item 42) in which "Not at all important" takes up $1.7 \%(\mathrm{~N}=5)$, "Not very important" 23.6\% ( $\mathrm{N}=71)$, "Important" 41.7\% ( $\mathrm{N}=125)$, "Very important" $21.3 \%(\mathrm{~N}=64)$, and "Totally important" $11.6 \%(\mathrm{~N}=35)$, with the mean of 3.18; and "Teacher as syllabus designer" (Item 37) in which "Not at all important" takes up 8.3\% $(\mathrm{N}=25)$, "Not very important" $26.6 \%(\mathrm{~N}=80)$, "Important" 30\% ( $\mathrm{N}=90)$, "Very important" 20.6\% (N=62), and "Totally important" $14.3 \%(\mathrm{~N}=43)$, with the mean of 3.06. The reported information is presented in Table 12.

Table 12. MTR-pertained responsibilities receiving medium ratings

\begin{tabular}{|c|c|c|c|c|c|c|}
\hline $\begin{array}{c}\text { Responsibilities pertaining to } \\
\text { teacher roles }\end{array}$ & $\begin{array}{l}\text { Not at all } \\
\text { important }\end{array}$ & $\begin{array}{c}\text { Not very } \\
\text { important }\end{array}$ & Important & $\begin{array}{c}\text { Very } \\
\text { important }\end{array}$ & $\begin{array}{c}\text { Totally } \\
\text { important }\end{array}$ & Mean \\
\hline 43. Teacher as learning evaluator & $0.6(\mathrm{~N}=2)$ & $6.7(\mathrm{~N}=20)$ & $36.6(\mathrm{~N}=110)$ & $40.3(\mathrm{~N}=121)$ & $15.6(\mathrm{~N}=47)$ & 3.64 \\
\hline 29. Teacher as responsibility share & $1.3(\mathrm{~N}=6)$ & $4.7(\mathrm{~N}=14)$ & $38.3(\mathrm{~N}=115)$ & $39.3(\mathrm{~N}=118)$ & $15.7(\mathrm{~N}=47)$ & 3.62 \\
\hline 35. Teacher as modernizer & $\mathrm{v}=7)$ & $4.6(\mathrm{~N}=14)$ & $39.3(\mathrm{~N}=118)$ & $37.3(\mathrm{~N}=112)$ & $16.3(\mathrm{~N}=49)$ & 3.61 \\
\hline 31. Teacher as learner & $=4)$ & $=28)$ & 36.6 & 02) & $=52)$ & 3.58 \\
\hline 30. Teacher as co-partic & $3.3(\mathrm{~N}=10)$ & $7.7(\mathrm{~N}=23)$ & $42.0(\mathrm{~N}=126)$ & $31.6(\mathrm{~N}=95)$ & $15.3(\mathrm{~N}=46)$ & 3.48 \\
\hline 36. Teacher as curriculum developer & $3.7(\mathrm{~N}=11)$ & $20.3(\mathrm{~N}=61)$ & $30.6(\mathrm{~N}=92)$ & $26.7(\mathrm{~N}=80)$ & $18.6(\mathrm{~N}=56)$ & 3.36 \\
\hline 26. Teacher as empowerer & $2.7(\mathrm{~N}=8)$ & $14.6(\mathrm{~N}=44)$ & $\mathrm{J}=116)$ & $32.7(\mathrm{~N}=98)$ & $\mathrm{N}=34)$ & 3.35 \\
\hline 41. Teacher as curriculum & 6.7( & $\mathrm{N}=30)$ & $=115)$ & $36.3(\mathrm{~N}=109)$ & $\mathrm{J}=26)$ & 3.30 \\
\hline 33. Teacher as friend & $2.0(\mathrm{~N}=6)$ & $15.6(\mathrm{~N}=47)$ & $47.0(\mathrm{~N}=141)$ & $28.6(\mathrm{~N}=86)$ & $6.7(\mathrm{~N}=20)$ & 3.22 \\
\hline 16. Teacher as social worker & $4.6(\mathrm{~N}=14)$ & $16.3(\mathrm{~N}=49)$ & $42.6(\mathrm{~N}=128)$ & $28.7(\mathrm{~N}=86)$ & $7.6(\mathrm{~N}=23)$ & 3.18 \\
\hline 42. Teacher as textbook evaluator & $1.7(\mathrm{~N}=5)$ & $23.6(\mathrm{~N}=71)$ & $41.7(\mathrm{~N}=125)$ & $21.3(\mathrm{~N}=64)$ & $11.6(\mathrm{~N}=35)$ & 3.18 \\
\hline 37. Teacher as syllabus designer & $8.3(\mathrm{~N}=25)$ & $26.6(\mathrm{~N}=80)$ & $30.0(\mathrm{~N}=90)$ & $20.6(\mathrm{~N}=62)$ & $14.3(\mathrm{~N}=43)$ & 3.06 \\
\hline
\end{tabular}

And the 3 MTR-pertained responsibilities receiving low ratings include: "Teacher as academic advisor" (Item 18) in which "Not at all important" accounts for $5.3 \%(\mathrm{~N}=16)$, "Not very important" 23\% (N=69), "Important"
$46.6 \%(\mathrm{~N}=140)$, "Very important" 20.3\% $(\mathrm{N}=61)$, and "Totally important" $4.7 \%$ $(\mathrm{N}=14)$, with the mean of 2.96; "Teacher as negotiator" (Item 28) in which "Not at all important" accounts for $20.3 \%(\mathrm{~N}=61)$, "Not 
very important" 31.6\% ( $\mathrm{N}=95)$, "Important" $30.3 \% \quad(\mathrm{~N}=91)$, "Very important" $14.3 \%$ $(\mathrm{N}=43)$, and "Totally important" $3.3 \%$ $(\mathrm{N}=10)$, with the mean of 2.49 ; and "Teacher as textbook developer/writer" (Item 38) in which "Not at all important" takes up 26.6\%
$(\mathrm{N}=80)$, "Not very important" $31.7 \%(\mathrm{~N}=95)$, "Important" 30.6\% (N=92), "Very important" $8.3 \%(\mathrm{~N}=25)$, and "Totally important" $2.6 \%$ $(\mathrm{N}=8)$ with the mean of 2.29. Table 13 provides a summary of the information.

Table 13. MTR-pertained responsibilities receiving low ratings

\begin{tabular}{|l|c|c|c|c|c|r|}
\hline $\begin{array}{c}\text { Responsibilities pertaining to teacher } \\
\text { roles }\end{array}$ & $\begin{array}{c}\text { Not at all } \\
\text { important }\end{array}$ & $\begin{array}{c}\text { Not very } \\
\text { important }\end{array}$ & Important & $\begin{array}{c}\text { Very } \\
\text { important }\end{array}$ & $\begin{array}{c}\text { Totally } \\
\text { important }\end{array}$ & Mean \\
\hline 18. Teacher as academic advisor & $5.3(\mathrm{~N}=16)$ & $23.0(\mathrm{~N}=69)$ & $46.6(\mathrm{~N}=140)$ & $20.3(\mathrm{~N}=61)$ & $4.7(\mathrm{~N}=14)$ & 2.96 \\
\hline 28. Teacher as negotiator & $20.3(\mathrm{~N}=61)$ & $31.6(\mathrm{~N}=95)$ & $30.3(\mathrm{~N}=91)$ & $14.3(\mathrm{~N}=43)$ & $3.3(\mathrm{~N}=10)$ & 2.49 \\
\hline 38. Teacher as textbook developer/writer & $26.6(\mathrm{~N}=80)$ & $31.7(\mathrm{~N}=95)$ & $30.6(\mathrm{~N}=92)$ & $8.3(\mathrm{~N}=25)$ & $2.6(\mathrm{~N}=8)$ & 2.29 \\
\hline
\end{tabular}

Objective 3: Findings relating to what roles Vietnamese EFL school teachers have performed and what roles they haven't performed in their actual teaching

Question 3: What roles have Vietnamese EFL school teachers performed and what roles haven't they performed in their actual teaching?

\section{EFL teachers' report on role categories performed and not performed}

It is noticeable that the results found in our research are not similar to those found in Karavas-Dukas's (1995) research. Of the
9 role categories, "Example of behaviour" (Category IX) receives very high percentage of performance: $96.1 \%$. This is followed by "Source of expertise" (Category I): 92.3\%, "Management" (Category II): 81.2\%, "Source of advice" (Category III): 81.2\%, and "Facilitation of learning" (Category IV): $75.4 \%$. The results of our research also indicate that there are 4 role categories receiving relatively low percentages of performance: "Care taking" (Category VI): 48.1\%, "Professional developing" (Category VII): 45.6\%, "Responsibility sharing" (Category V): 36.2\%, and "Assessing \& evaluating” (Category VIII): 30.5\%. Table 14 summarizes the information.

Table 14. EFL teachers' report on role categories performed and not performed

\begin{tabular}{|l|c|c|l|l|c|}
\hline \multicolumn{1}{|c|}{ Role category } & Performed & $\begin{array}{c}\text { Not } \\
\text { performed }\end{array}$ & \multicolumn{1}{|c|}{ Role category } & Performed & $\begin{array}{c}\text { Not } \\
\text { performed }\end{array}$ \\
\hline IX. Example of behaviour & 96.1 & 3.8 & VI. Care taking & 48.1 & 51.8 \\
\hline I. Source of expertise & 92.3 & 7.7 & VII. Professional developing & 45.6 & 54.3 \\
\hline II. Management & 81.2 & 18.7 & V. Responsibility sharing & 36.2 & 63.7 \\
\hline III. Source of advice & 78.5 & 21.4 & VIII. Assessing \& evaluating & 30.5 & 69.4 \\
\hline IV. Facilitation of learning & 75.4 & 24.5 & \multicolumn{4}{|c}{}
\end{tabular}

EFL teachers' report on TTRs performed and not performed

The results obtained from Questionnaire 3 show that almost all TTRs are reported having been performed: of the 12 TTRs identified as belonging to the TTS, $10(83.3 \%)$ are reported having been performed; and only 2 are reported not having been performed. It is of interest to note here that all the 10 TTRs reported having been performed by the 
EFL teachers receive very high percentages of performance (from 98.7\% down to $71.3 \%)$. Specifically, "Teacher as teacher and educator" (Item 1): 98.7\% ( $\mathrm{N}=296)$, “Teacher as manager" (Item 6): 97\% ( $\mathrm{N}=291)$, "Teacher as presenter of knowledge" (Item 2): $96.7 \%(\mathrm{~N}=290)$, "Teacher as language model" (Item 45): 96.6\% (N=290), “Teacher as example" (Item 44): 95.6\% ( $\mathrm{N}=287)$, "Teacher as source of knowledge" (Item 3): 95.3\% ( $\mathrm{N}=286)$, “Teacher as controller" (Item 11): $80.6 \%(\mathrm{~N}=242)$, “Teacher as tutor" (Item 19): $75 \%(\mathrm{~N}=225)$, "Teacher as authoritarian" (Item 12): $72 \%(\mathrm{~N}=216)$, and "Teacher as explainer" (Item 5): 71.3\% (N=214). Table 15 summarizes the information.

Table 15. TTRs reported having been performed and not performed by EFL school teachers

\begin{tabular}{|c|c|c|c|c|c|}
\hline Role item & Performed & $\begin{array}{c}\text { Not } \\
\text { performed }\end{array}$ & Role item & Performed & $\begin{array}{c}\text { Not } \\
\text { performed }\end{array}$ \\
\hline 1. Teacher and educator & $98.7(\mathrm{~N}=296)$ & $1.3(\mathrm{~N}=4)$ & $\begin{array}{l}\text { 3. Teacher as source of } \\
\text { knowledge }\end{array}$ & $95.3(\mathrm{~N}=286)$ & $4.7(\mathrm{~N}=14)$ \\
\hline 6. Teacher as manager & $97.0(\mathrm{~N}=291)$ & $3.0(\mathrm{~N}=9)$ & 11. Teacher as controller & $80.7(\mathrm{~N}=242)$ & $19.3(\mathrm{~N}=58)$ \\
\hline $\begin{array}{l}\text { 2. Teacher as presenter } \\
\text { of knowledge }\end{array}$ & $96.7(\mathrm{~N}=290)$ & $3.3(\mathrm{~N}=10)$ & 19. Teache & $75.0(\mathrm{~N}=225)$ & $25.0(\mathrm{~N}=75)$ \\
\hline $\begin{array}{l}\text { 45. Teacher as language } \\
\text { model }\end{array}$ & $96.7(\mathrm{~N}=290)$ & $3.3(\mathrm{~N}=10)$ & $\begin{array}{l}\text { 12. Teacher as } \\
\text { authoritarian }\end{array}$ & $72.0(\mathrm{~N}=216)$ & $28.0(\mathrm{~N}=84)$ \\
\hline 44. Teacher as example & $95.7(\mathrm{~N}=287)$ & $4.3(\mathrm{~N}=13)$ & 5. Teacher as explainer & $71.3(\mathrm{~N}=214)$ & $28.7(\mathrm{~N}=86)$ \\
\hline
\end{tabular}

The 2 TTRs reported not having been performed are: "Teacher as authority" (Item 13 ) receiving the ratio of $50.3 \%(\mathrm{~N}=151)$ nonperformance v. $49.6 \%(\mathrm{~N}=149)$ performance, and "Teacher as parent" (Item 32 ) receiving the ratio of $71.3 \%(\mathrm{~N}=214)$ non-performance $\mathrm{v}$. $28.7 \%(\mathrm{~N}=86)$ performance. The information described is summarized in Table 16.

Table 16. TTRs reported not having been performed by EFL school teachers

\begin{tabular}{|l|c|c|}
\hline \multicolumn{1}{|c|}{ Role item } & \multicolumn{1}{c|}{$\begin{array}{c}\text { Not } \\
\text { performed }\end{array}$} & Performed \\
\hline $\begin{array}{l}\text { 13. Teacher as } \\
\text { authority }\end{array}$ & $50.3((\mathrm{~N}=151)$ & $49.6(\mathrm{~N}=149)$ \\
\hline $\begin{array}{l}\text { 32. Teacher as parent } \\
\text { (mother/father) }\end{array}$ & $71.3((\mathrm{~N}=214)$ & $28.6(\mathrm{~N}=86)$ \\
\hline
\end{tabular}

\section{EFL teachers' report on MTRs performed and not performed}

Of the 33 teacher roles identified as belonging to the MTT, $22(66.7 \%)$ are reported having been performed and $11(33.3 \%)$ are reported not having been performed.

The 22 MTRs that are reported having been performed are: "Teacher as developer of language skills" (Item 4): 99.3\% ( $\mathrm{N}=298)$, “Teacher as planner" (Item 8): 98.3\% ( $\mathrm{N}=295)$, "Teacher as involver" (Item 25): 96.6\% $(\mathrm{N}=290)$, "Teacher as rapport builder" (Item 27): $96.6 \%(\mathrm{~N}=290)$, "Teacher as organizer" (Item 7): 95.7\% ( $\mathrm{N}=287)$, “Teacher as quality controller" (Item 15): 95.7\% ( $\mathrm{N}=287)$, "Teacher as stimulator" (Item 21): 95.7\% $(\mathrm{N}=287)$, "Teacher as test/exam developer" (Item 39): $95.7 \% \quad(\mathrm{~N}=287)$, "Teacher as observer" (Item 9): 95.3\% ( $\mathrm{N}=286)$, “Teacher as motivator" (Item 24): 94.3\% ( $\mathrm{N}=283)$, "Teacher as monitor" (Item 10): 93.6\% $(\mathrm{N}=281)$, "Teacher as test/exam preparer" (Item 40): $93.6 \% \quad(\mathrm{~N}=281)$, “Teacher as learning assessor" (Item 14): 92.7\% ( $\mathrm{N}=278)$, "Teacher as counsellor" (Item 17): 90.3\% $(\mathrm{N}=271)$, "Teacher as learning evaluator" (Item 43): $90.3 \% \quad(\mathrm{~N}=271)$, "Teacher as enabler" (Item 22): 81.3\% ( $\mathrm{N}=244)$, "Teacher as academic advisor" (Item 18): $70.3 \%$ $(\mathrm{N}=211)$, "Teacher as researcher" (Item 34): $69.3 \%(\mathrm{~N}=208)$, "Teacher as friend" (Item 33): $67.6 \%(\mathrm{~N}=203)$, "Teacher as inspirer" (Item 23): $60.6 \% \quad(\mathrm{~N}=182)$, "Teacher as 
modernizer" (Item 35): 60\% $(\mathrm{N}=180)$, and "Teacher as learning facilitator" (Item 20):

53.3\% ( $=166)$. Table 17 summarizes the information reported.

Table 17. MTRs reported having been performed by EFL school teachers

\begin{tabular}{|c|c|c|c|}
\hline Role item & Performed & Role category & Performed \\
\hline 4. Teacher as developer of language skills & $99.3(\mathrm{~N}=298)$ & 40. Teacher as test/exam preparer & $93.6(\mathrm{~N}=281)$ \\
\hline 8. Teacher as planner & $98.3(\mathrm{~N}=295)$ & 14. Teacher as learning assessor & $92.7(\mathrm{~N}=278)$ \\
\hline 25. Teacher as involver & $96.6(\mathrm{~N}=290)$ & 17. Teacher as counsellor & $90.3(\mathrm{~N}=271)$ \\
\hline 27. Teacher as rapport builder & $96.6(\mathrm{~N}=290)$ & 43. Teacher as learning evaluator & $90.3(\mathrm{~N}=271)$ \\
\hline 7. Teacher as organizer & $95.7(\mathrm{~N}=287)$ & 22. Teacher as enabler & $81.3(\mathrm{~N}=244)$ \\
\hline 15. Teacher as quality controller & $95.7(\mathrm{~N}=287)$ & 18. Teacher as academic advisor & $70.3(\mathrm{~N}=211)$ \\
\hline 21. Teacher as stimulator & $95.7(\mathrm{~N}=287)$ & 34. Teacher as researcher & $69.3(\mathrm{~N}=208)$ \\
\hline 39. Teacher as test/exam developer & $95.7(\mathrm{~N}=287)$ & 33. Teacher as friend & $67.6(\mathrm{~N}=203)$ \\
\hline 9. Teacher as observer & $95.3(\mathrm{~N}=286)$ & 23. Teacher as inspirer & $60.6(\mathrm{~N}=182)$ \\
\hline 24. Teacher as motivator & $94.3(\mathrm{~N}=283)$ & 35. Teacher as modernizer & $60.0(\mathrm{~N}=120)$ \\
\hline 10. Teacher as monitor & $93.6(\mathrm{~N}=281)$ & 20. Teacher as learning facilitator & $53.3(\mathrm{~N}=166)$ \\
\hline
\end{tabular}

The 11 MTRs reported not having been performed include: "Teacher as textbook developer/writer" (Item 38): 100\% ( $\mathrm{N}=300)$, "Teacher as curriculum developer" (Item 36): $99.7 \%(\mathrm{~N}=299)$, “Teacher as curriculum evaluator" (Item 41): 99.7\% ( $\mathrm{N}=299)$, "Teacher as syllabus designer" (Item 37): 99\% (N=297), "Teacher as negotiator": 97.6\%
$(\mathrm{N}=293)$, "Teacher as social worker" (Item 16): $77.3 \%(\mathrm{~N}=232)$, "Teacher as empowerer" (Item 26): $77.3(\mathrm{~N}=232)$, "Teacher as coparticipant/team member" (Item 30): 59.7\% $(\mathrm{N}=179)$, "Teacher as learner" (Item, 31): $58 \%(\mathrm{~N}=174)$, and "Teacher as responsibility sharer" (Item 29): 54.3\% ( $=161)$. Table 18 summarizes the information.

Table 18. MTRs reported not having been performed

\begin{tabular}{|c|c|c|c|}
\hline Role item & $\begin{array}{c}\text { Not } \\
\text { performed }\end{array}$ & Role item & Not performed \\
\hline $\begin{array}{l}\text { 38. Teacher as textbook developer/ } \\
\text { writer }\end{array}$ & $100(\mathrm{~N}=300)$ & 16. Teacher as social worker & $77.3(\mathrm{~N}=232)$ \\
\hline 36. Teacher as curriculum developer & $99.7(\mathrm{~N}=299)$ & 26. Teacher as empowerer & $77.3(\mathrm{~N}=232)$ \\
\hline 41. Teacher as curriculum evaluator & $99.7(\mathrm{~N}=299)$ & $\begin{array}{l}\text { 30. Teacher as co-participant/team } \\
\text { member }\end{array}$ & $59.7(\mathrm{~N}=179)$ \\
\hline 37. Teacher as syllabus designer & $99.4(\mathrm{~N}=298)$ & 31. Teacher as learner & $58.0(\mathrm{~N}=174)$ \\
\hline 42. Teacher as textbook evaluator & $99.0(\mathrm{~N}=297)$ & 29. Teacher as responsibility sharer & $54.3(\mathrm{~N}=161)$ \\
\hline 28. Teacher as negotiator & $97.6(\mathrm{~N}=293)$ & & \\
\hline
\end{tabular}

There are three noteworthy points here. First, a closer examination of the items in Table 17 will reveal that quite a few of the 22 MTRs reported having been performed can be of TTRs as well. Here we can find "Teacher as organizer" (Item 7), "Teacher as planner" (Item 8), "Teacher as test/exam developer" (Item 39), "Teacher as monitor" (Item 10), “Teacher as test/exam preparer" (Item 40), etc. Secondly, many of the 11 MTRs reported not having been performed in Table 18 belong to what Western (English) language teaching scholars such as Nunan (1987, 1991), Tudor (1993, 1996), Widdowson (1999), Hedge (2000), Richards (2005), Richards \& Rodgers (2001), and Graves (2005) refer to as the learner-centred approach in communicative language teaching. Here we 
can find "Teacher as textbook developer/ writer" (Item 38), "Teacher as curriculum developer" (Item 36), "Teacher as syllabus designer" (Item 37), "Teacher as textbook evaluator" (Item 42), "Teacher as negotiator" (Item 28), etc. And thirdly, except for the 3 items (30,31, and 29), the 8 other items reported not having been performed in Table 18 receive very high percentages of nonperformance (from $73.3 \%-100 \%$ ).

Objective 4: Locating the current Vietnamese EFL school teachers on the traditional $\leftrightarrow$ modern teacher style scale
Question 4: What style of teacher are Vietnamese EFL school teachers in this era of Industry 4.0 ?

We shall respond to this question by weaving together important findings obtained from the three survey questionnaires which are presented in sequence of "teacher role", "level of rating" (in terms of mean), and (roles) "performed" and (role) "not performed". Then based on the correlation between the interwoven findings we shall attempt to locate Vietnamese EFL school teachers on the traditional $\leftrightarrow$ modern teacher style scale. The data is presented in Tables 19, 20, and 21 below.

Table 19. TTRs given high/medium/low ratings, performed/not performed

\begin{tabular}{|c|c|c|c|c|}
\hline $\mathbf{N}^{0}$ & Traditional teacher role & High rating & Performed & Not performed \\
\hline 1 & Teacher as educator & 4.38 & $98.7(\mathrm{~N}=296)$ & $1.3(\mathrm{~N}=4)$ \\
\hline 2 & Teacher as presenter of knowledge & 4.05 & $96.7(\mathrm{~N}=290)$ & $3.3(\mathrm{~N}=10)$ \\
\hline 6 & Teacher as manager & 4.08 & $95.3(\mathrm{~N}=286)$ & $3.0(\mathrm{~N}=9)$ \\
\hline 44 & Teacher as an example & 3.95 & $95.6(\mathrm{~N}=287)$ & $4.3(\mathrm{~N}=13)$ \\
\hline \multicolumn{5}{|c|}{ Medium rating } \\
\hline 45 & Teacher as language model & 3.56 & $96.6(\mathrm{~N}=290)$ & $3.3(\mathrm{~N}=10)$ \\
\hline 3 & Teacher as source of knowledge & 3.54 & $95.3(\mathrm{~N}=286)$ & $4.7(\mathrm{~N}=14)$ \\
\hline 19 & Teacher as tutor & 3.44 & $75.0(\mathrm{~N}=225)$ & $25.0(\mathrm{~N}=75)$ \\
\hline 11 & Teacher as controller & 3.35 & $80.6(\mathrm{~N}=242)$ & $19.3(\mathrm{~N}=58)$ \\
\hline 5 & Teacher as explainer & 3.11 & $71.3(\mathrm{~N}=214)$ & $28.7(\mathrm{~N}=86)$ \\
\hline \multicolumn{5}{|c|}{ Low rating } \\
\hline 12 & Teacher as authoritarian & 2.85 & $72.0(\mathrm{~N}=216)$ & $28.0(\mathrm{~N}=84)$ \\
\hline 13 & Teacher as authority & 2.76 & $49.6(\mathrm{~N}=149)$ & $50.3(\mathrm{~N}=151)$ \\
\hline 32 & Teacher as parent & 2.28 & $28.8(\mathrm{~N}=86)$ & $71.7(\mathrm{~N}=214)$ \\
\hline
\end{tabular}

Table 20. MTRs given very high/high ratings and performed/not performed

\begin{tabular}{|l|l|c|c|c|}
\hline $\mathbf{N}^{0}$ & Teacher role & Very high rating & Performed & Not performed \\
\hline 21 & Teacher as stimulator & 4.43 & $95.6(\mathrm{~N}=287)$ & $4.3(\mathrm{~N}=13)$ \\
\hline 4 & Teacher as developer of language skills & 4.39 & $99.3(\mathrm{~N}=298)$ & $0.6(\mathrm{~N}=2)$ \\
\hline 24 & Teacher as motivator & 4.32 & $94.3(\mathrm{~N}=283)$ & $5.6(\mathrm{~N}=17)$ \\
\hline 25 & Teacher as involver & 4.25 & $96.6(\mathrm{~N}=290)$ & $3.3(\mathrm{~N}=10)$ \\
\hline 7 & Teacher as organizer & 4.17 & $95.6(\mathrm{~N}=287)$ & $4.3(\mathrm{~N}=13)$ \\
\hline 8 & Teacher as planner & 4.16 & $98.3(\mathrm{~N}=295)$ & $1.7(\mathrm{~N}=5)$ \\
\hline 23 & Teacher as inspirer & 4.16 & $60.6(\mathrm{~N}=182)$ & $39.3(\mathrm{~N}=118)$ \\
\hline
\end{tabular}




\begin{tabular}{|l|l|c|c|c|}
\hline 22 & Teacher as enabler & 4.02 & $81.3(\mathrm{~N}=244)$ & $18.7(\mathrm{~N}=56)$ \\
\hline \multicolumn{5}{|c|}{ High rating } \\
\hline 39 & Teacher as test/exam developer & 3.89 & $95.7(\mathrm{~N}=287)$ & $4.3(\mathrm{~N}=13)$ \\
\hline 10 & Teacher as monitor & 3.88 & $93.6(\mathrm{~N}=281)$ & $19.3(\mathrm{~N}=58)$ \\
\hline 27 & Teacher as rapport builder & 3.88 & $96.6(\mathrm{~N}=290)$ & $3.3(\mathrm{~N}=10)$ \\
\hline 20 & Teacher as learning facilitator & 3.85 & $53.3(\mathrm{~N}=166)$ & $44.7(\mathrm{~N}=134)$ \\
\hline 9 & Teacher as observer & 3.82 & $95.3(\mathrm{~N}=286)$ & $4.6(\mathrm{~N}=14)$ \\
\hline 40 & Teacher as test/exam preparer & 3.82 & $93.6(\mathrm{~N}=281)$ & $6.3(\mathrm{~N}=19)$ \\
\hline 15 & Teacher as quality controller & 3.80 & $95.6(\mathrm{~N}=287)$ & $4.3(\mathrm{~N}=13)$ \\
\hline 14 & Teacher as learning assessor & 3.79 & $92.7(\mathrm{~N}=278)$ & $7.3(\mathrm{~N}=22)$ \\
\hline 34 & Teacher as researcher & 3.78 & $69.3(\mathrm{~N}=208)$ & $30.6(\mathrm{~N}=92)$ \\
\hline 17 & Teacher as counsellor & 3.73 & $90.3(\mathrm{~N}=271)$ & $9.6(\mathrm{~N}=29)$ \\
\hline
\end{tabular}

Table 21. MTRs given medium/low ratings and performed/not performed

\begin{tabular}{|l|l|c|c|c|}
\hline $\mathbf{N}^{\mathbf{0}}$ & Teacher role & Medium rating & Performed & Not performed \\
\hline 43 & Teacher as learning evaluator & 3.64 & $90.3(\mathrm{~N}=271)$ & $9.6(\mathrm{~N}=29)$ \\
\hline 29 & Teacher as responsibility sharer & 3.62 & $46.7(\mathrm{~N}=119)$ & $54.3(\mathrm{~N}=162)$ \\
\hline 35 & Teacher as modernizer & 3.61 & $60.0(\mathrm{~N}=180)$ & $40.0(\mathrm{~N}=120)$ \\
\hline 31 & Teacher as learner & 3.58 & $42.0(\mathrm{~N}=126)$ & $58.0(\mathrm{~N}=174)$ \\
\hline 30 & Teacher as co-participant/team member & 3.48 & $40.3(\mathrm{~N}=121)$ & $59.7(\mathrm{~N}=129)$ \\
\hline 36 & Teacher as curriculum developer & 3.36 & $0.3(\mathrm{~N}=1)$ & $99.7(\mathrm{~N}=299)$ \\
\hline 26 & Teacher as empowerer & 3.35 & $22.6(\mathrm{~N}=68)$ & $77.3(\mathrm{~N}=232)$ \\
\hline 41 & Teacher as curriculum evaluator & 3.30 & $0.3(\mathrm{~N}=1)$ & $99.7(\mathrm{~N}=299)$ \\
\hline 33 & Teacher as friend & 3.22 & $67.6(\mathrm{~N}=203)$ & $32.3(\mathrm{~N}=97)$ \\
\hline 16 & Teacher as social worker & 3.18 & $22.7(\mathrm{~N}=68)$ & $77.3(\mathrm{~N}=232)$ \\
\hline 42 & Teacher as textbook evaluator & 3.18 & $1.0(\mathrm{~N}=3)$ & $99.0(\mathrm{~N}=297)$ \\
\hline 37 & Teacher as syllabus designer & 3.06 & $0.6(\mathrm{~N}=2)$ & $99.4(\mathrm{~N}=298)$ \\
\hline \multicolumn{7}{|c|}{ Low rating } & & $70.3(\mathrm{~N}=211)$ & $29.6(\mathrm{~N}=89)$ \\
\hline 18 & Teacher as academic advisor & 2.96 & $2.3(\mathrm{~N}=7)$ & $97.6(\mathrm{~N}=293)$ \\
\hline 28 & Teacher as negotiator & 2.49 & $0(\mathrm{~N}=0)$ & $100(\mathrm{~N}=300)$ \\
\hline 38 & Teacher as textbook developer/writer & 2.29 & & \\
\hline
\end{tabular}

Table 19 shows that of the 12 TTRs, 10 (83.3\%) (Items 1, 2, 6, 44, 45, 3, 19, 11, 5 and 12) are reported having been performed with very high percentages. Table 19 also indicates that generally there is a very strong correlation between what EFL teachers rate teacher roles as high and medium and what they report having performed these roles: all the 9 TTRs (Items 1, 2, 6, 44, 45, 3, 19, 11 and 5) rated as high and medium are reported having been performed. An exception is Item 12 (Teacher as authoritarian) where it is rated as low (mean=2.85), but is reported having been performed with a significantly high percentage: $72 \%(\mathrm{~N}=216)$.

Table 20 reveals that all 18 items of MTRs that are rated as very high and high are reported having been performed with very high and high percentages. Table 20 also suggests that there is a very strong correlation between "Very high rating" and "High rating" and very high percentages of "Performed": of the 18 items of MTRs, 15 (83.3\%) which receive "very high rating" and "high rating" 
are reported having been performed with very high percentages (from $81.3 \%$ to $99.3 \%$ ). Further, what seems to be of interest here is that many of these roles seem to be of both the TTS and MTS.

Table 21 presents a different picture: of the 15 MTRs that receive medium and low ratings, only 4 (26.6\%) (Items 43, 35, 33, and 18) are reported having been performed. What is noticeable here is that the remaining 11 roles that are reported not having been performed belong to what modern (English) language teaching scholars such as Nunan (1991), Tudor (1993, 1996), Widdowson (1999), Richards (2005), Richards \& Lockhart (1995), Richards \& Rodgers (2001), Graves (2005), Scrivener (2009), and many others refer to as the learner-centred approach with $6 / 11(54.5 \%)$ of them being given absolute or very high percentages: 100\% (Item 38), 99.7\% (Item 36), 99.7\% (Item 41), 99.4\% (Item 37), 99\% (Item 42), and 97.6\% (Item 28).

Now the question is "How should we situate the Vietnamese EFL school teachers on the traditional $\leftrightarrow$ modern teacher style scale?" It seems premature to give a definite answer. However, the interwoven findings presented in Tables 19, 20, and 21 have said enough to justify a conclusion. The fact that $83.3 \%(10 / 12)$ of the TTRs (including 1 lowly rated) and $66.7 \%(22 / 33)$ of the MTRs (many of which can be of both TTS and MTS) are reported having been performed, and the fact that of the remaining $33.3 \%$ (11/33) of the MTRs (many of which belong to the learnercentred approach) only $36.3 \%$ (4/11) are reported having been performed, suggest that although we are living in the era of Industry 4.0, many of the Vietnamese EFL school teachers are still on the traditional side of the traditional $\leftrightarrow$ modern teacher style scale.

\section{Conclusion}

Teachers play the most important role in the success of an educational system. They are an indispensable component in the teacher $\leftrightarrow$ learner $\leftrightarrow$ teaching material "eternal triangle" (Bolitho, 1990: 23). They are "many things" (Pullias \& Young, 1968, 1977), and they do many things to help their students gain knowledge and develop skills, and to educate them to become good and responsible citizens (cf. Bộ Giáo dục và Đào tạo [MoET], 2018). In this study we have attempted to look specifically at one of the many things teachers do in their work which does not seem to have received adequate attention from EFL/ESL educational research: how Vietnamese EFL school teachers perceive their roles in this current changing world. As the term "Industry 4.0" has been increasingly gaining currency in EFL/ESL education, we have made an attempt to locate the Vietnamese EFL school teachers on the traditional $\leftrightarrow$ modern teacher style scale as well. We have set an overarching aim and four guided objectives, and raised four related research questions. In response, we have employed three survey questionnaires to explore how Vietnamese EFL school teachers perceive their roles in terms of TTS and MTS, how they rate the importance of teacher responsibilities pertaining to the teacher roles, and what roles they have performed and what roles they haven't performed in their actual teaching. Weaving the results obtained from the statistical analyses together, we have been able to suggest the predominant style of the current Vietnamese EFL school teachers: they are more of the traditional teacher style than of the modern teacher style. The results of our study permit the following conclusions:

First, the surveyed Vietnamese EFL school teachers display a relatively good understanding of teacher roles: they can identify what teacher roles are of the TTS and 
what are of the MTS; they rate as high and medium most of the TTRs (9/12) and report having performed most of them (10/12); they rate as very high, high and medium most of the TTRs (30/33) and report having performed the majority of them (22/33); they are aware of their roles and of the trend in modern EFL education - the trend toward the learner-centred approach; they can recognize what roles are important to them at present and what roles are important to them in the years to come; they understand that besides traditional roles that are still maintained, there are new roles which the modern teacher should take. However, due to the pressure of various factors, particularly the current mismatch between EFL teaching and EFL testing (cf. Pham, 2016; Hoang, 2017) many of them still attach more special importance to traditional roles.

Secondly, at present many TTRs are still prevalent; the dominant EFL pedagogy in schools in Vietnam is still transmission pedagogy; and many Vietnamese school EFL teachers still communicate language knowledge. This explains why many English classrooms in schools in Vietnam are still crowded with non-communicative activities: teachers transmit language knowledge (with only one or two crippling language skills) to students and students have passively but happily to receive the knowledge presented to them as 'correct', and try to memorize the content presented and prepare to write down what they were taught in exam rooms.

Thirdly, along with the change in ELT methodology from traditional teaching methods to modern teaching ones there is a positive change in Vietnamese EFL school teachers' perception about their roles to meet the demands of the present and those of the future. This is manifested in the fact that they rate highly and report having performed most of the TTRs and the majority of MTRs, and that they employ both traditional and modern teaching methods to solve two contradictory problems of learning and teaching English in Vietnamese schools: on the one hand they have to teach communicative English meet the demand of the renovation in the new communicative English curriculum, new foreign language proficiency standards, new English textbooks, new teaching methodology and new communicative testing formats (for details of these, see Bộ Giáo dục và Đào tạo [MoET], 2010, 2012a, 2012b, 2014, 2018; Hoang, 2015, 2016, 2017, 2018); on the other hand they have to teach non-communicative English to satisfy the pressing need of "teaching for the test and teaching to the test" (see Hoang, 2017, 2018; for a world-wide view on this issue, see also Bachman, 1991; Bachman \& Palmer, 1996; Shohamy, 2001; Hughes, 2003; and Alderson, 2004), helping their students pass non-communicative tests/exams which are still pervasive in the Vietnamese school system. This explains why some TTRs which are not highly rated (and even seem to be outdated in modern EFL pedagogy) such as "Teacher as source of knowledge" (Item 2), "Teacher as controller" (Item 11), "Teacher as authoritarian" (Item 12) are still reported having been performed with very high percentages. This also explains why some MTRs which are rated as high and medium such as "Teacher as responsibility sharer" (Item 29), "Teacher as curriculum developer" (Item 36), "Teacher as curriculum evaluator" (Item 41) and others are reported not having been performed.

\section{Limitations and Recommendations}

As this research attempts to study how EFL school teachers in Vietnam perceive their roles and to identify what style of teachers they are, the data sample collected and analyzed on 300 EFL school teachers is still small. The generalization of the results is, therefore, limited. Further, as the participants involved 
in this research provide information through questionnaires; the research, no matter how comprehensive it may be, still lacks EFL teachers' voices or opinions on their roles and why these roles were responded as they were. Interviews and a larger data sample size, therefore, should be added to maximize the reliability and validity of the research (cf. Creswell \& Creswell, 2018).

Attention should be drawn to the fact that the present context of learning and teaching English in schools in Vietnam is different from those of learning and teaching English in many other countries, particularly in Western Europe and North America. In Vietnam, most school students learn the same English course throughout the school system; the number of students learning an English course is not just a dozen or a hundred but some hundred thousand; students learn English not in a class but in some ten thousand classes. Decisions on English standards, curriculum design, course goals, syllabus contents, teaching materials, teaching methods, assessment procedures, and class schedules are made at different levels of management bodies such as MoET, provincial departments of education, district departments of education, and schools. The EFL school teachers' task is to carry out those decisions that have been made, helping students to learn English, and leading them up from one grade to the next in the general school system. If the students do not succeed, it is the teacher's fault for not presenting the materials clearly enough. In a number of situations, if the EFL teacher does group work, her colleagues of other subjects will feel that she is not really teaching at all, and the complaint that is often lodged is that her class is making noises which disturb the learning of the other classes. However, the results obtained from our research have suggested that the future of EFL learning will be different. Face-to-face learning will not be the only means for the teacher to transmit knowledge and skills. Some traditional teacher roles will surely "retain an undiminished authority" (Widdowson, 1987: 87; 1999: 189; see also Finocchiaro, 1974; Oak, n.d.); but some others will be replaced or complemented by newer modern ones in response to the world of advanced technology where man and machine align to enable new teaching possibilities, learning together and from each other will dominate, teachers will be more as facilitators, students will be more as independent learners, and teaching and learning will be built around shared learning (Tudor, 1993, 1996; Nunan, 1999; Harmer, 2005). It is, therefore, recommended that teacher role should be a legitimate component in all EFL teacher training and teacher professional development (PD) programmes in English teacher education departments/faculties in Vietnam to help EFL teachers be better familiarized with teacher roles (what they are and what roles should and should not be performed in their teaching contexts, etc.). It is also recommended that EFL school teachers should be given opportunities to exercise teacher roles, particularly those required in modern EFL/ESL education, so that they can perform their roles more effectively and appropriately in their teaching for the success of their students as they move along their "journey of learning" (Pullias \& Young, 1968: 32) English - the most important means of international communication in the world of Industry 4.0 .

\section{Acknowledgements}

The author would like to thank the following colleagues for helping collect and analyse parts of the data for this research: Dr. Nguyen Viet Hung of VNU ULIS Faculty of Language Education and Professional Development, $\mathrm{Mr}$ Le Thanh Quy of Nguyen Binh Khiem Lower and Upper Secondary School - Cau Giay District, and Mr Nguyen Van Ket of VietnamPoland Upper Secondary School. 


\section{References}

\section{Vietnamese}

Bộ Giáo dục và Đào tạo (MoET) (2010). Chuoong trình tiếng Anh thi điểm tiểu học (Pilot English Curriculum for Vietnamese Primary Schools). (Ban hành theo Quyết định số 3321/QĐ-BGDĐT ngày 12 tháng 8 năm 2010 của Bộ trưởng Bộ Giáo dục và Đào tạo).

Bộ Giáo dục và Đào tạo (MoET) (2012a). Chuong trình giáo dục phổ thông môn tiếng Anh thi điểm cấp trung hoc co' sở (Pilot English Curriculum for Vietnamese Lower Secondary Schools). (Ban hành theo Quyết định số 01/QĐ-BGDĐT ngày 03 tháng 01 năm 2012 của Bộ trưởng Bộ Giáo dục và Đào tạo).

Bộ Giáo dục và Đào tạo (MoET) (2012b). Chuong trình giáo dục phổ thông môn tiếng Anh thi điểm cấp trung hoc phổ thông (Pilot English Curriculum for Vietnamese Upper Secondary Schools). (Ban hành theo Quyết định số 5290/QĐ-BGDĐT ngày 23 tháng 11 năm 2012 của Bộ trưởng Bộ Giáo dục và Đào tạo).

Bộ Giáo dục và Đào tạo (MoET) (2014). Khung năng lục ngoại ngũ 6 bậc dùng cho Việt Nam (Six-level Foreign Language Proficiency Framework for Vietnam). (Ban hành kèm theo Thông tư số 01/2014/ TT-BGDĐT ngày 24 tháng 01 năm 2014 của Bộ trưởng Bộ Giáo dục và Đào tạo).

Bộ Giáo dục và Đào tạo (MoET) (2016a). Định dạng đề thi đánh giá năng lục sủ dụng tiếng Anh bậc 1 theo Khung năng lục ngoại ngũ 6 bạc dùng cho Việt Nam (dành cho học sinh tiểu học) (Test Format for Assessing the Ability to Use Level 1 English according to the Six-level Foreign Language Competency Framework for Vietnamese). (Ban hành theo Quyết định 1479/QĐ-BGDĐT ngày 10 tháng 5 năm 2016 của Bộ trưởng Bộ Giáo dục và Đào tạo).

Bộ Giáo dục và Đào tạo (MoET) (2016b). Định dạng đề thi đánh giá năng lục sư dụng tiếng Anh bậc 2 theo Khung năng lực ngoại ngũ 6 bậc dùng cho Việt Nam (dành cho học sinh trung hoc co sớ) (Test Format for Assessing the Ability to Use Level 2 English according to the Six-level Foreign Language Competency Framework for Vietnamese). (Ban hành theo Quyết định số 1475/QĐ-BGDĐT ngày 10 tháng 5 năm 2016 của Bộ trưởng Bộ Giáo dục và Đào tạo).

Bộ Giáo dục và Đào tạo (MoET) (2016c). Định dạng đề thi đánh giá năng lục sủ dụng tiếng Anh bậc 3 theo Khung năng lực ngoại ngũu 6 bậc dùng cho Việt Nam (dành cho hoc sinh trung hoc phổ thông) (Test Format for Assessing the Ability to Use Level 3 English according to the Six-level Foreign Language Competency Framework for Vietnamese). (Ban hành theo Quyết định số 1477/QĐ-BGDĐT ngày 10 tháng 5 năm 2016 của Bộ trưởng Bộ Giáo dục và Đào tạo).
Bộ Giáo dục và Đào tạo (MoET) (2018). Chuoong trình giáo dục phổ thông môn tiếng Anh (General English Education Curriculum). (Ban hành theo Thông tư số 32/2018/TT-BGDĐT ngày 26 tháng 12 năm 2018 của Bộ trưởng Bộ Giáo dục và Đào tạo).

Phạm Việt Hà (2016). Bài thi trung học phổ thông quốc gia môn tiếng Anh năm 2015: Phân tích trên cơ sở các tài liệu công khai (The 2015 National Matriculation and General Certificate of Secondary Education English Test: An Analysis Based on Publicized Data). (Trong) Kỷ yếu hội thảo quốc gia: Đổi mói phurong pháp giảng dạy và kiểm tra, đánh giá trong giáo dục ngoại ngũ. Hà Nội: Nxb. Đại học Quốc gia Hà Nội. 64-71.

\section{English}

Alderson, J. C. (2004). The Shape of Things to Come: Will it be the Normal Distribution? (In) European Language Testing in a Global Context Proceedings of the ALTE Barcelona Conference July 2001. M. Milanovic, C. Weir, \& S. Bolton (Eds.). Cambridge: CUP. 1-26.

Archana, S. \& K. Usha Rani (2016). Role of a Teacher in English Language Teaching (ELT). International Journal of Educational Science and Research (IJESR), 1-3.

Bachman, L. (1991). Fundamental Considerations in Language Testing. Second Impression. Oxford, UK: Oxford University Press.

Bachman, L. F. \& A. S. Palmer (1996). Language Testing in Practice. Oxford, England: Oxford University Press.

Banton, M. (1965). Roles: An Introduction to the Study of Social Relations. London: Tavistock Publications.

Bargiela-Chiappini, F., C. Nickerson \& B. Planken (2007). Business Discourse. Candlin, N. C. \& D. R. Hall (Eds.). New York: Palgrave MacMillan.

Bolitho, R. (1990): An Eternal Triangle? Roles for Teacher, Learners and Teaching Materials in a Communicative Approach. (In) Language Teaching Methodology for the Nineties. Anivan, S. (Ed.). SEAMEO: Regional Language Centre.

Breen, M. P., \& C. N. Candlin (1980). The Essentials of a Communicative Curriculum in Language Teaching. Applied Linguistics, 1(2), 89-112.

Brown, J. D. (2007). Using Surveys in Language Programs. Second Edition. Cambridge: Cambridge University Press.

Cohen, L., L. Manion \& K. Morrison (2007). Research Methods in Education ( $6^{\text {th }}$ Ed.). New York, USA: Palgrave MacMillan.

Creswell, J. W. \& Creswell, D. J. (2018). Research Design: Qualitative, Quantive, and Mixed Methods Approaches. Fifth edition. Washington D.C.: Sage.

De Lopez, C. L. C. (1994). The Role of the Teacher 
in Today's Language Classroom. (In) Teacher Development: Making the Right Moves. Selected Articles from the ENGLISH TEACHING FORUM 1980-1993. Kral, T. (Ed.). Washington D.C.: English Language Program Division. 9-17.

Ellis, R. \& A. McClinton(1990). If You Take My Meaning: Theory into Practice in Human Communication. London: Edward Arnold.

Finocchiaro, M. (1974). English as a Second Language. New Edition. New York: Regents Publishing Company, Inc.

Graves, K. (2005). Teachers as Course Developers. (In) Teachers as Course Developers. Graves, K. (Ed.). Cambridge: Cambridge University Press.

Harmer, J. (2005). The Practice of English Language Teaching. Third Edition. Malaysia: Longman.

Hedge, T. (2000). Teaching and Learning in the Language Classroom. Oxford: Oxford University Press.

Hoang V. V. (2015). The Development of the Ten-Year English Textbook Series for Vietnamese Schools under the National Foreign Languages 2020 Project: A Cross-Cultural Collaborative Experience. $V N U$ Journal of Foreign Studies, 31(3), 1-17.

Hoang, V. V. (2016). Renovation in Curriculum Design and Textbook Development: An Effective Solution to Improving the Quality of English Teaching in Vietnamese Schools in the Context of Integration and Globalization. VNU Journal of Science: Education Research, 32(4), 9-20.

Hoang, V.V. (2017). The 2016 National Matriculation and General Certificate of Secondary Education English Test: A Challenge to the Goal of Foreign Language Education in Vietnamese Schools. VNU Journal of Science: Education Research, 3(4), 1-16.

Hoang, V.V. (2018). MoET's Three Pilot English Language Communicational Curricula for Schools in Vietnam: Rationale, Design and Implementation. VNU Journal of Foreign Studies, 34(2), 1-25.

Hughes, A. (2003). Testing for Language Teachers. Second Edition. Cambridge: Cambridge University Press.

Hyland, K. (1991). Collaboration in the Language Classroom. Prospect 7(1), 85-92.

Hymes, D. (1972). On Communicative Competence. (In) Sociolinguistics. Pride, J.B. \& J. Holmes (Eds.). England: Penguin Books Ltd.

Ikram Benzouine (November 8, 2012). The Mediocre Teacher Tells, the Great Teacher Inspires. (In) Marocco World News. Retrieved from https://www. moroccoworldnews.com/2012/11/64224/themediocre-teacher-tells-the-great-teacher-inspires/

Jones, L. (2007). The Student-centered Classroom. Cambridge: Cambridge University Press.

Keller, T. (2011). The Various Roles of the Teacher in the Classroom. GRIN Verlag: Open Publishing GmbH.
Oak, M. (n.d). Textbooks versus Computer Teaching. (In) http://www.buzzle.com/articles/textbooks-versuscomputer-teaching.html (retrieved on October 2, 2018).

Nunan, D. (1987). The Teacher as Curriculum Developer. Sydney: National Curriculum Resource Centre, Adult Migrant Education Programme.

Nunan, D. (1991). The Learner-Centred Curriculum. Fourth printing. Cambridge: Cambridge University Press.

Prodromou, L. (1994). The Good Language Teacher. (In) Teacher Development: Making the Right Moves. Selected Articles from the ENGLISH TEACHING FORUM 1980-1993. Kral, T. (Ed.). Washington D.C.: English Language Program Division, 18-33.

Pullias, E. V. \& J. D. Young (1968). A Teacher is Many Things. Ladder Edition. Greenwich, Cnn.: Fawcett Publications, Inc.

Pullias, E. V. \& J. D. Young (1977). A Teacher is Many Things. Second Edition. Bloomington and London: Indiana University Press.

Richards, J. C. \& C. Lockhart (1995). Reflective Teaching in Second Language Classrooms. Second Printing. Cambridge: Cambridge University Press.

Richards, J.C. \& Rodgers, T.S. (1996/2001). Approaches and Methods in Language Teaching. Cambridge: Cambridge University Press.

Robinson, P. C. (1991). ESP Today: A Practitioner's Guide. UK: Prentice Hall International.

Scrivener, J. (2009). Learning Teaching: A Guide Book for English Language Teachers. Second Edition. Oxford: MacMillan.

Shohamy, E. (2001). The Power of Tests: A Critical Perspective on the Uses of Language Tests. Singapore: Peason Education.

Taylor, B. (1987). Teaching ESL: Incorporating a Communicative, Student-centred Component. (In) Long, M. H. \& J. C. Richards (Eds.) Methodology in TESOL: A Book of Readings. New York: Newbury House.

Tikunoff, W. (1985). Developing Student Functional Proficiency: Part 1. Gainesville: University of Florida.

Tudor, I. (1993). Teacher Roles in the Learner-centred Classroom. ELT Journal, 47(1), 22-31.

Tudor, I. (1996). Learner-centredness as Language Education. Cambridge: Cambridge University Press.

Trochin, W. M. K., (2005). Research Method (The Concise Knowledge Base). Ohio, USA: Atomic Dog Publishing.

Widdowson, H.G. (1987). The Roles of Teacher and Learner. ELT Journal, 41(2), 83-8.

Widdowson, H.G. (1999). Aspects of Language Teaching. Oxford: Oxford University Press. 


\title{
“TRUYỀN CẢM HỨNG VÀ THÀNH CÔNG CHO MỌI HỌC SINH”: GIÁO VIÊN TIẾNG ANH Ở TRƯỜNG PHỔ THÔNG VIÊTT NAM NHẬN THỨC NHƯ THẾ NÀO VỀ VAI TRÒ CỦA HỌ VÀ HỌ THUỘC KIỂU PHONG CÁCH GIÁO VIÊN NÀO TRONG KỈ NGUYÊN CÔNG NGHIỆP 4.0?
}

\author{
Hoàng Văn Vân \\ Truoòng Đại học Ngoại ngũu - Đại học Quốc gia Hà Nội \\ Phạm Văn Đồng, Cầu Giấy, Hà Nội, Việt Nam
}

Tóm tắt: Nghiên cứu này cố gắng làm nổi bật việc giáo viên tiếng Anh ở trường phổ thông Việt Nam nhận thức như thế nào về vai trò của họ, và họ thuộc kiểu phong cách giáo viên nào trong thế giới hiện tại đang thay đổi - thế giới của Nền công nghiệp 4.0. Nghiên cứu bao gồm một mẫu 300 giáo viên tiếng Anh phổ thông ở Việt Nam. Công cụ sử dụng để nghiên cứu là ba phiếu hỏi nhằm mục đích khám phá các khía cạnh khác nhau trong nhận thức của giáo viên về vai trò của họ. Dữ liệu thu thập được phân tích theo định lượng và được thảo luận chi tiết. Nghiên cứu thu được một số kết quả quan trọng, trong đó năm kết quả sau đây là nổi bật: (i) giáo viên tiếng Anh ở trường phổ thông Việt Nam thể hiện sự hiểu biết tương đối tốt trong việc xác định vai trò nào thuộc phong cách của người giáo viên truyền thống và vai trò nào thuộc phong cách của người giáo viên hiện đại; (ii) họ đánh giá ở mức cao và mức trung bình hầu hết các vai trò của người giáo viên thuộc phong cách truyền thống và báo cáo đã thực hiện hầu hết các vai trò đó; (iii) họ đánh giá ở mức thấp một số vai trò của người giáo viên thuộc phong cách truyền thống, nhưng báo cáo vẫn tiếp tục thực hiện những vai trò đó; (iv) họ đánh giá ở các mức rất cao, cao và trung bình hầu hết các vai trò thuộc phong cách của người giáo viên hiện đại, nhưng chỉ có $2 / 3$ trong số đó được báo cáo là đã được thực hiện; (v) họ đánh giá ở mức trung bình nhiều vai trò thuộc phong cách của người giáo viên hiện đại còn lại, các vai trò thường được gọi trong giáo dục tiếng Anh như là một ngoại ngữ/như là một ngôn ngữ thứ hai là đường hướng lấy người học làm trung tâm trong dạy ngôn ngữ giao tiếp, nhưng dựa vào những thông tin đan kết lại thu được từ ba phiếu hỏi, nghiên cứu gợi ý rằng mặc dù thời đại Công nghiệp 4.0 đang là một thực tế, nhưng nhiều giáo viên tiếng Anh ở trường phổ thông Việt Nam dường như vẫn ở phía truyền thống trên thang phong cách giáo viên truyền thống ↔ hiện đại. Từ thực tế trên, nghiên cứu khuyến nghị rằng vai trò giáo viên phải là một thành phần trong tất cả các chương trình đào tạo và bồi dưỡng giáo viên tại các khoa đào tạo tiếng Anh ở Việt Nam để giúp giáo viên làm quen tốt hơn với những vai trò của họ, đặc biệt là những vai trò cần thiết trong giáo dục tiếng Anh như là một ngoại ngữ/như là một ngôn ngữ thứ hai trong kỉ nguyên hiện đại để họ có thể thực hiện hiệu quả hơn và phù hợp hơn các vai trò của mình trong dạy học vì sự thành công của học sinh trong "hành trình học" (Pullias \& Young, 1968: 32) một công cụ giao tiếp mới.

Tư khóa: vai trò giáo viên, vai trò giáo viên truyền thống, vai trò giáo viên hiện đại, trách nhiệm liên quan đến vai trò của giáo viên, thang phong cách giáo viên truyền thống $\leftrightarrow$ hiện đại 


\section{Appendix 1 (Questionnaire 1)}

Dear teachers, thank you for agreeing to take part in our research. We highly appreciate your help in completing this survey questionnaire.

Your personal background:

1. You name:

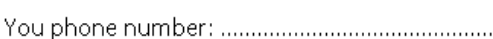

2. You are: $\square$ a primary teacher

3. You are: $\square$ male $\square$ female

4. You have been teaching English for:

a lower secondary teacher

an upper secondary teacher

5. You are teaching English in:

over 20 years

Which of the following teacher roles do you think are of the traditional teacher style and which ones are of the modern teacher style? [Please tick ( $V$ ) the right box]

\begin{tabular}{|c|c|c|}
\hline \multirow[t]{2}{*}{ Teacher role } & \multicolumn{2}{|c|}{ Teacher style } \\
\hline & Traditional & Moderr \\
\hline \multicolumn{3}{|l|}{ I. Source of expertise } \\
\hline \multicolumn{3}{|c|}{ 1. Teacher as teacher and educator } \\
\hline \multicolumn{3}{|c|}{ 2. Teacher as presenter of knowledge } \\
\hline \multicolumn{3}{|l|}{ 3. Teacher as source of knowledge } \\
\hline \multicolumn{3}{|c|}{ 4. Teacher as developer of language skills } \\
\hline \multicolumn{3}{|l|}{ 5. Teacher as explainer } \\
\hline \multicolumn{3}{|l|}{ II. Management } \\
\hline \multicolumn{3}{|l|}{ 6. Teacher as manager } \\
\hline \multicolumn{3}{|l|}{ 7. Teacher as organizer } \\
\hline \multicolumn{3}{|l|}{ 8. Teacher as planner } \\
\hline \multicolumn{3}{|l|}{ 9. Teacher as observer } \\
\hline \multicolumn{3}{|l|}{ 10. Teacher as monitor } \\
\hline \multicolumn{3}{|l|}{ 11. Teacher as controller } \\
\hline \multicolumn{3}{|l|}{ 12. Teacher as authoritarian } \\
\hline \multicolumn{3}{|l|}{ 13. Teacher as authority } \\
\hline \multicolumn{3}{|l|}{ 14. Teacher as learning assessor } \\
\hline \multicolumn{3}{|l|}{ 15. Teacher as quality controller } \\
\hline \multicolumn{3}{|l|}{ 16. Teacher as social worker } \\
\hline \multicolumn{3}{|l|}{ III. Source of advice } \\
\hline \multicolumn{3}{|l|}{ 17. Teacher as counsellor } \\
\hline \multicolumn{3}{|l|}{ 18. Teacher as academic advisor } \\
\hline \multicolumn{3}{|l|}{ 19. Teacher as tutor } \\
\hline \multicolumn{3}{|l|}{ IV. Facilitation of learning } \\
\hline \multicolumn{3}{|l|}{ 20. Teacher as learning facilitator } \\
\hline \multicolumn{3}{|l|}{ 21. Teacher as stimulator } \\
\hline \multicolumn{3}{|l|}{ 22. Teacher as enabler } \\
\hline \multicolumn{3}{|l|}{ 23. Teacher as inspirer } \\
\hline \multicolumn{3}{|l|}{ 24. Teacher as motivator } \\
\hline \multicolumn{3}{|l|}{ 25. Teacher as involver } \\
\hline 26. Teacher as empowerer & & \\
\hline 27. Teacher as rapport builder & & \\
\hline V. Responsibility sharing & & \\
\hline
\end{tabular}




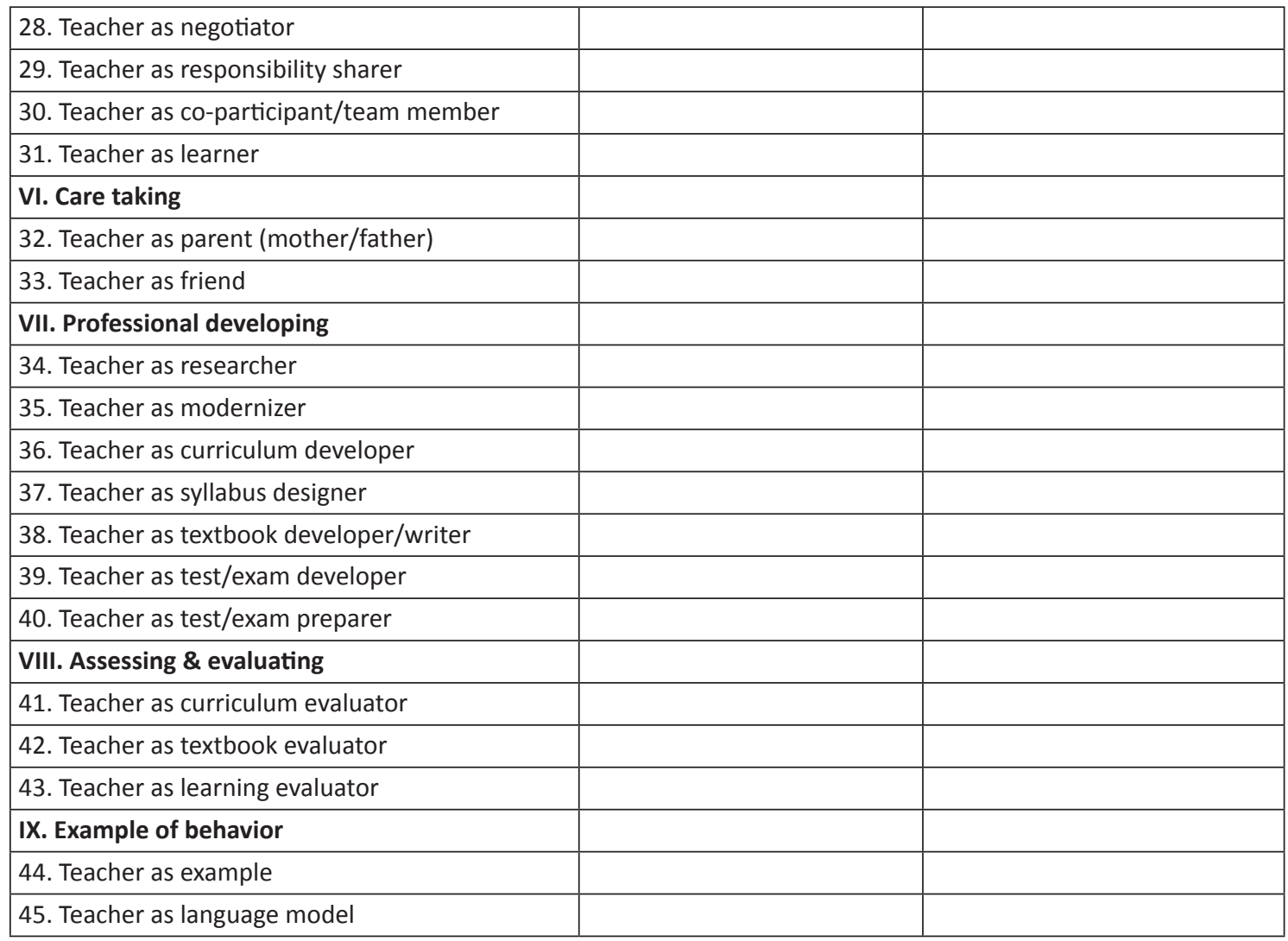

Thank you for your cooperation.

\section{Appendix 2 (Questionnaire 2)}

Dear teachers, thank you for agreeing to take part in our research. We highly appreciate your help in completing this survey questionnaire.

Your personal background:

1. You name: ................................................... You phone number:

2. You are: $\square$ a primary teacher $\square$ alower secondary teacher $\square$ an upper secondary teacher

3. You are: male female

4. You have been teaching English for: $\square$ 1-10 years $\square$ 11-20 years $\square$ over 20 years

5. You are teaching English in: $\square$ rural area $\square$ suburban area $\square$ urban area

In your experience, which of the following responsibilities is
1. Not at all important?
[Please tick (V) column 1]
2. Notvery important?
[Please tick (V) column 2]
3. Important?
[Please tick (V) column 3]

\section{Very important? \\ [Please tick ( $\mathrm{V}$ ) column 4]}
5. Totally important?
[Please tick (V) column 5]

\begin{tabular}{|c|c|c|c|c|c|c|}
\hline No & Responsibilities & 1 & 2 & 3 & 4 & 5 \\
\hline I. & Source of expertise & & & & & \\
\hline 1 & $\begin{array}{l}\text { The teacher helps students to learn things they do not know or have not yet } \\
\text { known and understand what they learn; and educates them to become good and } \\
\text { responsible citizens. }\end{array}$ & & & & & \\
\hline 2 & $\begin{array}{l}\text { The teacher provides students with knowledge of English pronunciation, vocabulary, } \\
\text { grammar, and English culture. }\end{array}$ & & & & & \\
\hline 3 & $\begin{array}{l}\text { The teacher helps students by providing them with a word/phrase or an expression } \\
\text { when they are writing or tells students where to look for a book or a website. }\end{array}$ & & & & & \\
\hline
\end{tabular}




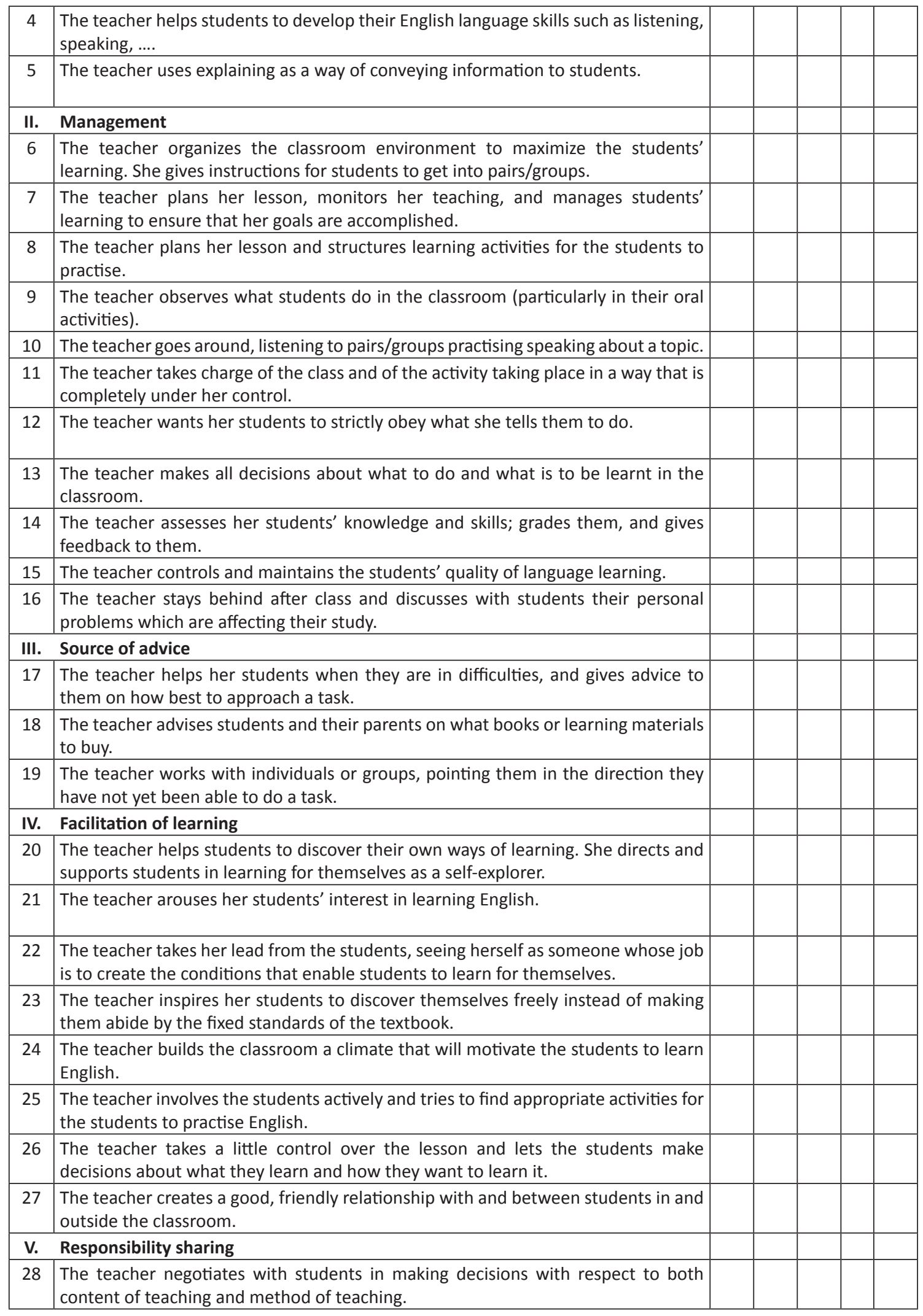




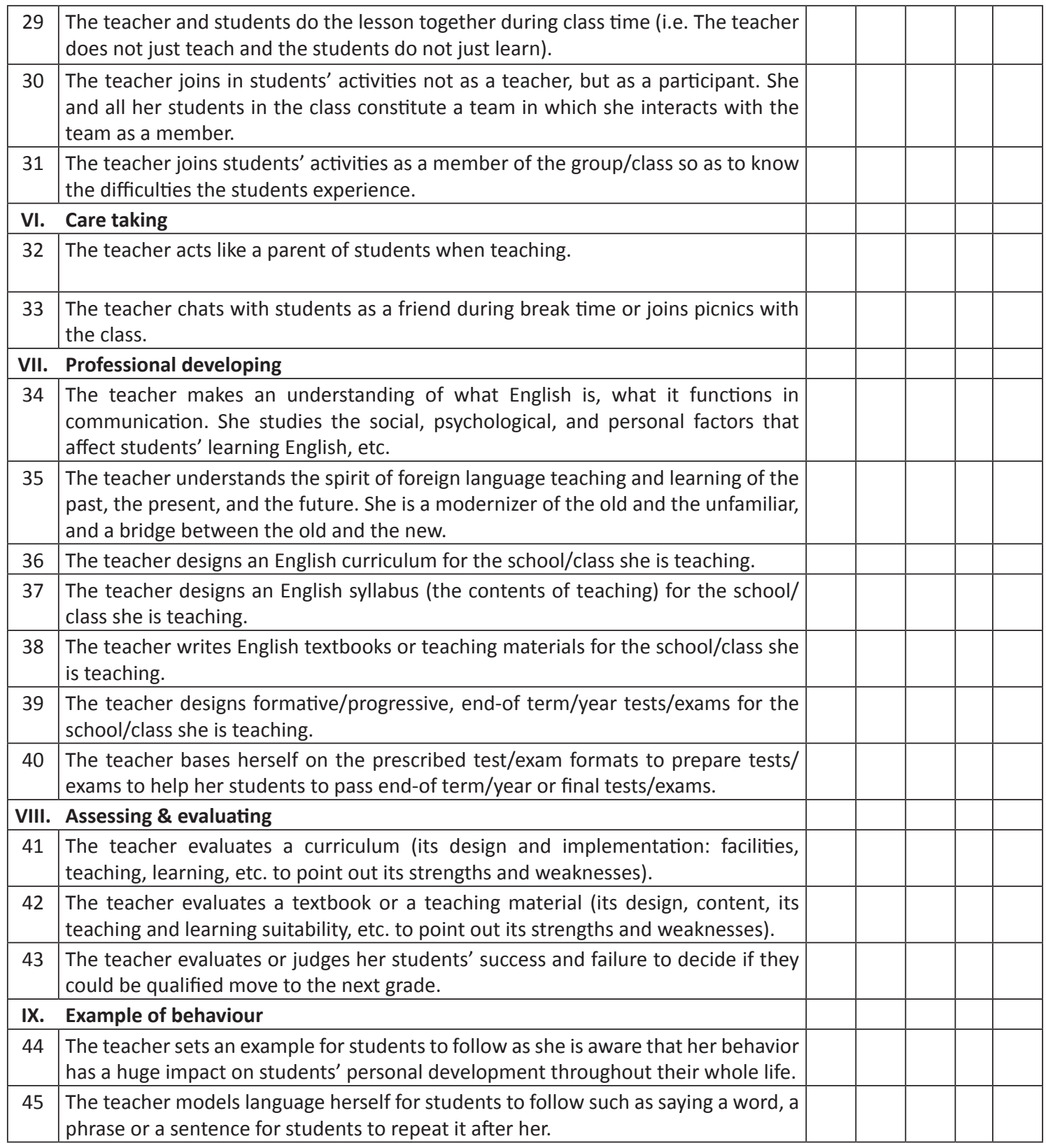

Thank you for your cooperation

\section{Appendix 3 (Questionnaire 3)}

Dear teachers, thank you for agreeing to take part in our research. We highly appreciate your help in completing this survey questionnaire.

\section{Your personal background:}

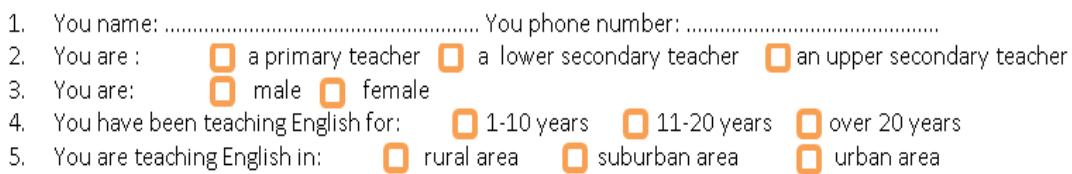

Which of the following teacher roles

1. have you performed or are you performing?

2. haven't you performed or are you not performing?
[Please tick ( $V$ ) the boxes in column 1] [Please tick ( $V$ ) the boxes in column 2] 


\begin{tabular}{|c|c|c|}
\hline Role category/item & Role performed & Role not performed \\
\hline \multicolumn{3}{|l|}{ I. Source of expertise } \\
\hline \multicolumn{3}{|l|}{ 1. Teacher and educator } \\
\hline \multicolumn{3}{|l|}{ 2. Teacher as presenter of knowledge } \\
\hline \multicolumn{3}{|l|}{ 3. Teacher as source of knowledge } \\
\hline \multicolumn{3}{|l|}{ 4. Teacher as developer of language skills } \\
\hline \multicolumn{3}{|l|}{ 5. Teacher as explainer } \\
\hline \multicolumn{3}{|l|}{ II. Management } \\
\hline \multicolumn{3}{|l|}{ 6. Teacher as manager } \\
\hline \multicolumn{3}{|l|}{ 7. Teacher as organizer } \\
\hline \multicolumn{3}{|l|}{ 8. Teacher as planner } \\
\hline \multicolumn{3}{|l|}{ 9. Teacher as observer } \\
\hline \multicolumn{3}{|l|}{ 10. Teacher as monitor } \\
\hline \multicolumn{3}{|l|}{ 11. Teacher as controller } \\
\hline \multicolumn{3}{|l|}{ 12. Teacher as authoritarian } \\
\hline \multicolumn{3}{|l|}{ 13. Teacher as authority } \\
\hline \multicolumn{3}{|l|}{ 14. Teacher as learning assessor } \\
\hline \multicolumn{3}{|l|}{ 15. Teacher as quality controller } \\
\hline \multicolumn{3}{|l|}{ 16. Teacher as social worker } \\
\hline \multicolumn{3}{|l|}{ III. Source of advice } \\
\hline \multicolumn{3}{|l|}{ 17. Teacher as counsellor } \\
\hline \multicolumn{3}{|l|}{ 18. Teacher as academic advisor } \\
\hline \multicolumn{3}{|l|}{ 19. Teacher as tutor } \\
\hline \multicolumn{3}{|l|}{ IV. Facilitation of learning } \\
\hline \multicolumn{3}{|l|}{ 20. Teacher as learning facilitator } \\
\hline \multicolumn{3}{|l|}{ 21. Teacher as stimulator } \\
\hline \multicolumn{3}{|l|}{ 22. Teacher as enabler } \\
\hline 23. Teacher as inspirer & & \\
\hline 24. Teacher as motivator & & \\
\hline 25. Teacher as involver & & \\
\hline 26. Teacher as empowerer & & \\
\hline 27. Teacher as rapport builder & & \\
\hline V. Responsibility sharing & & \\
\hline 28. Teacher as negotiator & & \\
\hline 29. Teacher as responsibility sharer & & \\
\hline 30. Teacher as co-participant/team m & & \\
\hline 31. Teacher as learner & & \\
\hline VI. Care taking & & \\
\hline 32. Teacher as parent (mother/father & & \\
\hline 33. Teacher as friend & & \\
\hline VII. Professional developing & & \\
\hline 34. Teacher as researcher & & \\
\hline 35. Teacher as modernizer & & \\
\hline 36. Teacher as curriculum developer & & \\
\hline
\end{tabular}




\begin{tabular}{|l|l|l|}
\hline \multicolumn{1}{|c|}{ Role category/item } & Role performed & Role not performed \\
\hline 37. Teacher as syllabus designer & & \\
\hline 38. Teacher as textbook developer/writer & & \\
\hline 39. Teacher as test/exam developer & & \\
\hline 40. Teacher as test/exam preparer & & \\
\hline VIII. Assessing \& evaluating & & \\
\hline 41. Teacher as curriculum evaluator & & \\
\hline 42. Teacher as textbook evaluator & & \\
\hline 43. Teacher as learning evaluator & & \\
\hline IX. Example of behaviour & & \\
\hline 44. Teacher as example & & \\
\hline 45. Teacher as language model & & \\
\hline
\end{tabular}

Thank you for your cooperation 